NBER WORKING PAPER SERIES

\title{
A DOCTOR WILL SEE YOU NOW: PHYSICIAN-PATIENT RELATIONSHIPS AND CLINICAL DECISIONS
}

\author{
Erin Johnson \\ M. Marit Rehavi \\ David C. Chan, Jr \\ Daniela Carusi \\ Working Paper 22666 \\ http://www.nber.org/papers/w22666 \\ NATIONAL BUREAU OF ECONOMIC RESEARCH \\ 1050 Massachusetts Avenue \\ Cambridge, MA 02138
}

September 2016, Revised October 2022

This paper has benefited from discussions with and comments by: Kate Baicker, Loren Baker, Paul Beaudry, Marika Cabral, Zack Cooper, Joe Doyle, Nicole Fortin, Richard Freeman, Nancy Gallini, Josh Gottlieb, David Green, Florian Hoffman, Mireille Jacobson, Brendan Nyhan, Torsten Persson, Heidi Williams, Crystal Yang, and participants at ASHEcon, AHEC, the Canadian Institute for Advanced Research, the Junior Health Economists Summit, the Robert Wood Johnson Scholars in Health Policy Conference (Michigan), and seminars at the University of British Columbia, the University of Toronto, the University of Victoria, and Wellesley College. Chan acknowledges funding from NIH DP5OD01993-01 and Johnson and Rehavi acknowledge funding from NIH HD081369. We thank Sam Bock, Noah Boden-Gologorsky, Tessa Johnson, and Saam Zahedian for excellent research assistance. The views expressed herein are those of the authors and do not necessarily reflect the views of the National Bureau of Economic Research.

NBER working papers are circulated for discussion and comment purposes. They have not been peer-reviewed or been subject to the review by the NBER Board of Directors that accompanies official NBER publications.

(C) 2016 by Erin Johnson, M. Marit Rehavi, David C. Chan, Jr, and Daniela Carusi. All rights reserved. Short sections of text, not to exceed two paragraphs, may be quoted without explicit permission provided that full credit, including $\odot$ notice, is given to the source. 
A Doctor Will See You Now: Physician-Patient Relationships and Clinical Decisions

Erin Johnson, M. Marit Rehavi, David C. Chan, Jr, and Daniela Carusi

NBER Working Paper No. 22666

September 2016, Revised October 2022

JEL No. I11,J44

\section{ABSTRACT}

We provide novel estimates of the causal impact of physician-patient relationships on physicians' decisions. Exploiting quasi-random assignment of patients to OBs at childbirth, we find OBs are $25 \%$ likelier to perform $\mathrm{C}$-sections when delivering patients they have a preexisting clinical relationship with (their "own patients"). This effect is increasing in the relationship's strength. OBs also curtail labor sooner, are less likely to employ other invasive procedures (e.g., vacuum or forceps), and avoid complications of long and difficult births for their own patients.

Erin Johnson

Wellesley Centers for Women

Wellesley College

106 Central Street

Wellesley, MA 02481-8203

erinmj@mit.edu

M. Marit Rehavi

University of British Columbia

997-1873 East Mall

Vancouver, BC V6T 1Z1

and CIFAR

marit.rehavi@ubc.ca
David C. Chan, Jr

Department of Health Policy

117 Encina Commons

Stanford, CA 94305

and NBER

david.c.chan@stanford.edu

Daniela Carusi

75 Francis St., Boston MA 02115

dcarusi@partners.org 
The US has shifted to more finely specialized and fragmented healthcare delivery models. Hospitalists - physicians who provide inpatient care in place of the patient's personal physicianwere virtually nonexistent when Wachter and Goldman (1996) first identified the phenomena. When "hospital medicine" became a board certified specialty in 2009 , there were already almost 30,000 hospitalists. The specialty's dramatic growth continued; as of 2020 approximately 80,000 hospitalists have privileges in US hospitals, making it one of the largest medical specialties. ${ }^{1}$ The adoption of hospitalists has been particularly notable in obstetrics. As of 2010, 38\% of hospitals already reported employing obstetric hospitalists ("laborists"), obstetricians (OBs) who handle labor and delivery but who do not provide prenatal care (Srinivas et al. 2012). Organizing care in this manner clearly has implications for workflow and specialization. It also alters the physician-patient relationship. How does this rearrangement of physician-patient relationships affect health care?

The influences of financial incentives, malpractice concerns, and other self-interested motivations on physicians' decisions are well documented. Less understood, but potentially as important, is how physicians' relationships with their patients affect physicians' decisions. We use the setting of obstetrics to study this question. Prenatal care includes a concentrated set of interactions allowing patients to establish relationships with a single $\mathrm{OB}$. The exact timing of childbirth is often a random event, which matches the patient with the OB on call, who may or may not have had a prenatal relationship with the patient. As a result (and in contrast to many other clinical settings), strong physician-patient relationships at the time of delivery are unlikely to be correlated with confounding patient characteristics (e.g., poor health, a high affinity for medical care, or generous insurance). Rather, under random assignment to the delivering OB (herein "DOB"), patients with a strong relationship with the DOB should be the same as patients with a weak relationship with that particular DOB. The same OB, on the same day, in the same hospital, will treat patients with whom she has a longstanding relationship and patients with whom she has had little, if any, prior contact. Unlike in other settings with random assignment of patients to physicians or hospitalists (e.g., studies comparing assignment to a hospitalist or an outpatient doctor), random assignment of patients to relationships at delivery enables us to abstract away from cross-physician differences in practice 1. Authors' calculations from the American Hospital Association's Annual Survey (see Appendix A.1). 
style (Epstein and Nicholson 2009) or skill (Chan, Gentzkow, and Yu 2022; Currie and MacLeod 2013) and from other policy changes that may accompany a hospital reorganizing care to introduce hospitalists.

We isolate the causal effect of the physician-patient relationship on physician treatment decisions and patient health by exploiting the unique organizational features of labor and delivery. We exploit the call schedules of three OB groups at a leading academic medical center. The DOB for a patient in these practices is the physician who is on call when the patient is ready to deliver. We find that OBs are $25 \%$ more likely to perform a C-section (4 ppts) for patients with whom they had a prenatal relationship. This effect is large and robust, and its magnitude increases with the OB's familiarity with the patient. Consistent with Card, Fenizia, and Silver (Forthcoming) finding that marginal treatment decisions during childbirth are provider-driven, our analyses suggest these treatment differences are driven by physicians.

Examining other actions and outcomes, we find evidence consistent with OBs receiving greater disutility from their own patients' complications or risk. ${ }^{2}$ When treating their own patients, OBs appear to end labor sooner and substitute C-sections for less invasive procedures with modestly elevated risks of injury. OBs are $25 \%$ (2.5 ppts) less likely to employ vacuum extraction or forceps on their own patients, procedures that are associated with higher rates of maternal injury. When OBs deliver their own patients, the mothers are significantly less likely to experience complications of long or difficult labors, such as a laceration requiring repair, fevers, and other birth trauma. ${ }^{3}$ The gains from avoiding these complications appear to offset the extra hospital stay from the higher C-section rate. There is virtually no difference in hospital stays. The infants of OBs' own patients have health outcomes comparable to those of the other infants they deliver.

2. This could arise because OBs care more about their own patients, but need not result from altruistic motives. They may perceive different reputation risk when delivering their own patients or may simply want to minimize future follow-up care to treat complications (postnatal visits occur with the prenatal $\mathrm{OB}$ ).

3. Birth trauma refers to any condition listed under ICD-9 665 "other obstetrical trauma" and includes damage to internal structures (e.g. uterine rupture, uterine inversion, high vaginal laceration, pelvic hematoma, etc.). 


\section{Existing Literature}

The growth of hospitalist care models has changed the nature of physician-patient relationships. Several studies compare care delivered in hospitalist and primary-care-based models (Abenhaim et al. 2007; Iriye et al. 2013; Meltzer et al. 2002; Nijagal et al. 2015; Wachter and Goldman 2002). The implementation of a hospitalist model is a large bundled intervention at the hospital level. Randomized treatment by a hospitalist versus an outpatient physician is also a bundled treatment at the physician level. These studies conflate the effects of care continuity, physician incentives, specialization, and other physician characteristics associated with selection into hospital medicine. Understanding the channels driving these effects is essential for policy design, particularly policies that may reorganize care for the same set of physicians and patients. Our study isolates the effect of the preexisting physician-patient relationship and inpatient-outpatient care continuity while holding fixed provider identities, specialization in inpatient care, and the patient mix.

The strength of physician-patient relationships is a central component of discussions on fragmentation and care continuity. The fragmentation literature has focused on the potential for information loss and duplicated effort with multiple providers. Several studies have documented a crosssectional association between fragmented care, spending, and health outcomes (Romano, Segal, and Pollack 2015; Skinner, Staiger, and Fisher 2006). Agha, Frandsen, and Rebitzer (2017) find those who move to areas with higher fragmentation increase health care utilization. Chandra, Wright, and Howell (2012) show that an intervention increasing care continuity in a hospitalist group decreased length of stay and hospital charges. Similarly, two experimental studies find evidence that care

continuity improves outcomes and lowers costs (Wachter et al. 1998; Wasson et al. 1984). Sabety (2022) finds a $4 \%$ increase in mortality after patients lose their primary care providers.

On the patient side, qualitative research finds patients express greater satisfaction with physicians they know (Mager and Andrykowski 2002). When treated by physicians they know, patients are more likely to adhere to recommendations (Kim, Kaplowitz, and Johnston 2004) and less likely to sue following adverse outcomes (Levinson et al. 1997). There is also experimental evidence that patients' beliefs about physician expertise are increasing in the number of visits with the physician 
(Wasson et al. 1984). Individuals are willing to pay higher health insurance premiums to continue seeing providers they know (Dahl and Forbes 2016), and half of all patients choose to follow a primary care physician who moves 40 minutes away (Sabety 2022).

Whether and how physician-patient relationships affect medical decisions remains unclear. Despite the value that patients place on physician-patient relationships, the American Medical Association warns that close prior relationships can cloud clinical judgment and recommends physicians refrain from treating close family members, as "personal feelings may unduly influence his or her professional medical judgment" (AMA 1993). More broadly, a growing economics literature has examined how social connections alter the way subjects internalize the interests of others (Bandiera, Barankay, and Rasul 2009; Hoffman, McCabe, and Smith 1996). A literature in psychology examines how social connections reduce "psychological distance" and may alter perceptions and decisions related to socially connected individuals, in similar ways as temporal or spatial distance (see, e.g., Trope and Liberman (2010) for a systematic review). In particular, decisions made on behalf of socially connected individuals appear similar to decisions made for oneself and are more likely to exhibit heuristic biases, such as loss aversion and the availability heuristic (Beisswanger et al. 2003; Caruso 2008; Hsee and Weber 1997; Polman 2012). Emotional investment, which may feature more strongly between socially connected individuals, can exacerbate cognitive biases. Decision-makers in emotional states, for example, typically overreact and overweight short-run or present gains (see, e.g., Loewenstein 2000, 2005).

\section{Clinical Background: Childbirth}

Prenatal care typically begins around the 10th week of pregnancy. The recommended schedule of visits amounts to 12 prenatal visits over the remaining 30 weeks of an uncomplicated pregnancy. This concentrated, high volume of visits creates the opportunity to establish a strong physicianpatient relationship.

The primary treatment decision once labor has begun is the delivery method: vaginal birth or C-section. Vaginal birth is the American Congress of Obstetricians and Gynecologists' preferred delivery method in uncomplicated labors (ACOG 2014). Vaginal deliveries avoid major abdominal 
surgery and associated maternal mortality and morbidity (Hall and Bewley 1999; Lydon-Rochelle et al. 2000). They utilize fewer resources, require shorter hospital stays, and avoid adverse effects of uterine scar tissue on future pregnancies (Alpay, Saed, and Diamond 2008; Ananth, Smulian, and Vintzileos 1997; Norberg and Pantano 2016) and fertility (Halla et al. 2020).

However, vaginal delivery is neither safe nor possible for all patients. Vaginal deliveries have a higher incidence of perineal lacerations and pelvic floor damage, which can lead to sexual dysfunction and incontinence (Fenner et al. 2003; Kammerer-Doak and Rogers 2008). As labor progresses OBs must weigh the desire to avoid an unnecessary C-section against the risks of allowing labor to continue with a long or difficult vaginal delivery. Allowing labor to progress when infants are not tolerating it well can result in brain damage or infant death (Baskett et al. 2007). Long labors are also associated with maternal fever and infection (Allen et al. 2009), and C-sections become riskier after a lengthy second stage (Pergialiotis et al. 2020). Forceps and vacuum extraction can expedite delivery and potentially avoid a C-section, but the application of force to extract the infant can result in neonatal birth injury and perineal trauma, with rates as high as $20 \%$ for the latter (Bailit et al. 2016).

\section{Empirical Strategy}

\section{III.A. The hospital and physician practices}

The setting for this study is a large, elite academic hospital in the US with a highly ranked obstetrics program. The hospital has a $31 \% \mathrm{C}$-section rate, close to the national rate of $32 \%$ in 2014 . We focus on deliveries performed by the three physician groups, herein Groups A, B, and C, for whom we are able to observe records from both outpatient prenatal visits and inpatient deliveries. Group A is owned by the same firm as the hospital, and its OBs are salaried. Groups B and C are private practices where OBs in each group pool revenue. ${ }^{4}$ Group A has an average of seven OBs who perform 851 deliveries per year. Groups B and C have three OBs each and average 412 and 301 deliveries per year, respectively. All the groups only employ "attending physicians" and do not

4. Even within groups B and C, the financial incentive to perform a C-section is diffuse and small. Payments from Blue Cross Blue Shield do not vary with birth method, and payments from other insurers are only 5-10\% higher for C-sections. 
utilize medical residents or students except as assistants during $\mathrm{C}$-sections. The groups treat patients of average medical risk and have similar practice styles. They choose to induce labor $(35 \%, 34 \%$, and $34 \%)$ and perform unscheduled C-sections $(16 \%, 15 \%$, and 16\%) at nearly identical rates.

Patients designate an OB as their prenatal provider. Patients may choose to see other OBs in the group for prenatal care, but the overwhelming majority of their visits are with their chosen prenatal OB. The groups employ a shared call model. One OB is designated as on-call during each shift and handles all group patient deliveries that occur during that shift. The groups' offices are not located at the hospital, and the on-call OB does not schedule clinic appointments during her call shift. The OBs rigorously follow these rules. We only observe more than one OB delivering during a shift on extremely busy days when a pre-designated back-up OB was called in to assist. Groups B and $\mathrm{C}$ share call with each other (i.e., the OB on call handles all deliveries from both groups) with the payment for the delivery going to the prenatal provider's group. Groups B and C do not share an office, and do not see each other's patients for prenatal appointments. All groups inform patients of the shared call model during their first prenatal visit, and the post-natal follow-up visit is scheduled with the patient's prenatal OB.

\section{III.B. Data and Key Variables}

The data used in this study come from the hospital's electronic medical record (EMR) and billing databases, covering both inpatient and outpatient care. The EMR provides the date and time of the birth, delivery method, information on clinical risk, complications arising during labor and delivery, and infant Apgar scores. The billing record includes up to 12 diagnosis and procedure codes for each mother and infant, providing standardized information on patient risk, treatments, and outcomes. It also includes the Diagnosis Related Group (DRG) along with admission and discharge dates. We augment these data with patient demographics, including age, race, and ZIP code.

Between 2006 and 2012, 10,408 babies were delivered by physicians in the three practices. $^{5}$ We match the hospital birth record to all outpatient prenatal care visits in the 40 weeks prior to the estimated due date. We exclude 500 multiple births, 1 birth with a missing estimated due date,

5. For practices $\mathrm{B}$ and $\mathrm{C}$, the sample begins in October of 2006 because their prenatal visit data is only available beginning in March of 2006. 
1,837 Group A and 34 Group B and C patients who received their prenatal care at a different site and therefore do not match to prenatal records, leaving 8,036 births.

OBs may schedule C-sections without attempting labor when laboring is likely to lead to a poor outcome and schedule delivery via medical induction of labor when continuing the pregnancy is unsafe. The exogenous variation in our paper comes from the idiosyncratic timing of the natural onset of labor. Scheduled C-sections and scheduled inductions do not have a random onset of labor and are excluded. After these exclusions, 3,800 unscheduled births remain. 15 births with missing parity or mother's ZIP code are also excluded for a final estimation sample of 3,785 births.

In this sample, the average and median patients each have in excess of $75 \%$ of their prenatal visits with their prenatal $\mathrm{OB}$. In contrast, when the $\mathrm{OB}$ delivers a colleague's patient, she is treating a woman for whom, on average, she provided less than $5 \%$ of the prenatal care. We therefore use whether the $\mathrm{OB}$ is the primary prenatal provider as an indicator for the presence of a preexisting physician-patient relationship. We define an OB's own patients as those patients who saw the OB for the majority of their prenatal care (87\% of the time, the first OB seen for prenatal care is also the most frequently seen $\mathrm{OB})$.

Among patients with a natural onset of labor, OBs deliver 711 of their own patients (19\%) and 3,074 of their colleagues' patients (Table 1). OBs are much more familiar with their own patients; the median patient delivered by their prenatal OB has had 9 prenatal visits with them. In contrast, $70 \%$ of patients delivered by another OB have met that OB prior to labor, and $18 \%$ of them have had only one prenatal visit with them. ${ }^{6}$

\section{Econometric Model and Results}

For patients with a natural onset of labor, the predetermined shared call schedule means the DOB is quasi-randomly assigned. Consistent with this, DOBs' own patients are statistically indistinguishable from the patients of other providers whom they deliver (Table 1$){ }^{7}$ The two groups have similar demographic and socioeconomic characteristics and comparable clinical risk factors. The only no-

6. Figure A.3 shows the full distribution.

7. The table shows statistics unadjusted for any fixed effects (e.g., time categories or OBs). The balance between these two groups of patients considers differences within DOBs by design. 
table difference is that the DOB's own patients are slightly less likely to be experiencing a first birth. Predicted C-section probabilities based on all of the variables in Table 1 do not significantly differ across DOB's own and others' patients. Moreover, the results that follow are robust to limiting the sample to first births or to first births with no risk factors.

If the DOB is quasi-randomly assigned, the differences in means across treatments and outcomes estimate the causal effects of delivering one's own patient relative to a colleague's patient. This represents the effect of the same OB operating in a traditional care vs. hospitalist model. We find substantive and significant differences in treatment evident even in the raw means (Table 2). The C-section rate when OBs deliver their own patients is $20.1 \%$. It is more than 4 percentage points lower, at $15.4 \%$, when delivering another OB's patient. This differential also increases with the OB's familiarity with the patient. Figure 1 presents the mean C-section rate when the OB delivers her own patients and colleagues' patients, by quintiles in the number of prenatal visits the primary prenatal $\mathrm{OB}$ had with the patient. The $\mathrm{C}$-section differential is highest when $\mathrm{OBs}$ deliver patients with whom they had the most contact during pregnancy. There is no significant $\mathrm{C}$-section differential when OBs deliver patients who are nominally their patient, but with whom they had little contact prior to the delivery ( 6 or fewer visits). ${ }^{8}$

However, we find that OBs do not treat their patients more intensively on all margins. OBs are approximately 30\% (3 ppts) less likely to employ vacuum extraction and forceps on their own patients, are more likely to allow them to forgo continuous electronic fetal monitoring (EFM), and are less likely to order ultrasounds during labor and delivery. There is no difference in their use of epidural anesthesia, reflecting that nearly all patients receive epidurals in our sample. There is also no difference in the use of labor-augmenting drugs.

We estimate OLS regressions, making use of the full set of clinical and demographic controls:

$$
y_{i}=\alpha \mathrm{Own}_{i}+\mathbf{X}_{i}^{\prime} \beta+\zeta_{j(i)}+\eta_{p(i)}+\epsilon_{i}
$$

$y_{i}$ is an outcome variable for patient $i$. Fixed effects for prenatal provider $p(i)$ control for any

8. The same pattern emerges when patients are grouped by the percent of prenatal visits with their primary prenatal OB (Figure A.2). 
prenatal sorting by unobserved patient characteristics to providers and groups, while fixed effects for the DOB $j(i)$ absorb each DOB's practice style in the delivery room. $\mathrm{Own}_{i}$ is an indicator that the patient was delivered by their prenatal OB (i.e., $\mathrm{Own}_{i} \equiv \mathbf{1}(j(i)=p(i))$ ), and $\mathbf{X}_{i}$ is a set of all variables listed under "Socioeconomic Status" and "Risk Factors" in Table 1.

\section{IV.A. C-Sections}

Table 3 displays OLS results for C-sections. The substantial treatment differences documented in the raw means persist in these results. All else equal, patients delivered by their own prenatal provider are 3.9 percentage points (25\%) more likely to receive a C-section (column 1 ). The estimates are unchanged by the inclusion of prenatal and DOB fixed effects (column 2). They are also robust to defining the prenatal $\mathrm{OB}$ as the first $\mathrm{OB}$ the patient saw in the practice (column 3) instead of the most frequently seen $\mathrm{OB}$ and to restricting the sample to women giving birth for the first time (Table 3B, column 1). In summary, we find that this effect is a general and robust phenomenon. ${ }^{9}$

If the physician-patient relationship is driving this treatment effect, the effect should be concentrated among the OBs' patients with the strongest prior relationship. To test this, we create an indicator for the patient's fraction of visits with her prenatal OB being above the median (79\%) and interact it with $\mathrm{Own}_{i}$. We find that the C-section differential comes from patients who had abovemedian fractions of their prenatal appointments with their DOB (column 5). While the fraction of prenatal visits scheduled with the patient's primary prenatal OB is not random, it does not appear to be correlated with patients' need or preferences for C-sections. When not delivered by their prenatal OBs, patients with above median fractions of prenatal visits with their prenatal OBs have the same C-section rate as patients with less concentrated prenatal care. The same pattern emerges when using the fraction of prenatal care provided by the DOB in lieu of Own $\left(\right.$ column 4). ${ }^{10}$ A one-standard deviation increase in the fraction of visits provided by the DOB is associated with a 1.8 percentage point increase in the $\mathrm{C}$-section rate.

9. The estimates are robust to using a logistic regression in lieu of OLS (Appendix Table A.4), to the inclusion of year fixed effects along with their interaction with the DOB fixed effects (Appendix Table A.5), and to using the number of visits with the DOB in lieu of the share of visits (Appendix Table A.5). The estimates are not driven by the effect of any individual OB and are robust to excluding each DOB in turn (Appendix Table A.3).

10. This is not our preferred specification because the share of visits with the primary prenatal OB is within the patient's control. 
Consistent with quasi-random assignment to DOBs, the ex-ante predicted probability of a Csection is the same for deliveries of one's own and others' patients. However, policies can be violated. Of most concern would be if the prenatal OB came in specially for high-risk situations that are also more likely to result in a C-section. We use the exact timing of all births in the practices to reconstruct each shift and find no evidence of this. Furthermore, the point estimates are unchanged when the sample is limited to first births with no preexisting conditions (Table 3B, column 2), a group unlikely draw extra concern. They are also robust to excluding preterm births (Table 3B, column 3), infants with a high risk of adverse outcomes. The other threat to identification would occur if scheduled C-sections or inductions were not recorded as such and slipped into the sample. The rich EMR data enabled us to verify that each of the unscheduled C-sections in our sample was either emergent or occurred after an attempt at labor. This would not be the case if the sample included any unidentified scheduled C-sections. The estimates are also robust to excluding all women with diagnoses for which a scheduled C-section is recommended (Table 3B, column 4), and to excluding births after 41 weeks (Table 3B, column 5), when inductions are most likely to occur. $^{11}$

A natural question is whether these findings represent patients selecting their prenatal OBs to perform their C-section when there might be flexibility in the DOB. Patients and DOBs delivering near shift changes could consider the identity of the next on-call provider and speed up or delay a transition to surgical delivery. Estimates excluding births 3 hours before or after a shift change are similar and not smaller than the full sample effect (Table A.2). Estimates are also robust to excluding the shifts with a high volume of births (more than 4 births) when a second DOB may be called in to assist and patients may choose between the two DOBs (Table A.2).

\section{IV.B. Other Treatment Decisions}

In addition to $\mathrm{C}$-sections, we also examine the impact of relationships on other treatment decisions and on health outcomes. The results are summarized in Table $4 .{ }^{12}$ Because some occur infrequently

11. At the time of these births, an attempt at vaginal birth was considered contraindicated for women with placenta previa, a prior classical C-section, and malpresented infants.

12. Regression estimates broken out by birth parity can be found in Table A.6, Table A.7, and Table A.8 
we estimate logit models in place of OLS for all binary outcomes.

Vacuum and forceps are used in $9 \%$ of vaginal births (assisted vaginal delivery). These tools can be lifesaving in a difficult delivery but can also cause injury. These complications may be particularly salient to the OB as they occur while she performs the procedure. OBs are 2.5 percentage points $(26 \%)$ less likely to choose to use these tools on their own patients. Women delivered by their own OBs also have shorter second stages of labor (the "pushing phase"). OBs appear to be intervening earlier and avoiding more difficult deliveries when they have a preexisting relationship with the mother. The patient's own OB is also 3.5 percentage points (38\%) more likely to allow her to forgo continuous EFM. ${ }^{13}$

\section{IV.C. Maternal and Infant Outcomes}

We estimate the effect of being delivered by one's prenatal OB for each maternal and infant health outcome that occurs in at least $1 \%$ of births using logistic regression. The most serious adverse outcome, mortality, is too rare to study in a sample of this size. We use the length of the hospital stay as a summary measure of care required for maternal recovery, and estimate OLS models of log length of stay on the own-patient indicator.

Patients delivered by their prenatal OBs have 3.2 percentage point (19\%) lower complication rates. Most of this comes from lower rates of fever (1.9 ppts or 25\%) and birth trauma (1.2 ppts or $43 \%)$. They also have fewer lacerations serious enough to require repair. ${ }^{14}$

The gains from avoiding these long and difficult deliveries appear to offset the extra hospital stay to recover from the higher C-section rate. Patients delivered by their prenatal OBs have hospital stays that are only $2 \%$ (less than 2 hours) longer (Table 4), nearly an order of magnitude less than what one would expect given their higher C-section rate. ${ }^{15}$ We cannot say whether the lower rates of birth trauma and lacerations requiring repair are associated with less long-run pelvic floor damage

13. Continuous EFM allows remote monitoring and is convenient for providers, but limits patient mobility.

14. These are not a mechanical result of fewer vaginal births. All but laceration repair are robust to the inclusion of controls for C-section and assisted vaginal delivery (Table A.7) and are known to be more prevalent in prolonged labors irrespective of delivery method.

15. Length of stay is time from admission to discharge and includes time in labor. C-section births average a $67 \%$ longer hospital stay (Table A.10). We obtain equivalent estimates for length measured in days (Table A.9). There is also no measurable difference in infant length of stay (Table A.10). Absent catastrophic complications, infants are not discharged before their mothers complicating interpretation of their length of stay. 
and thus improved quality of life.

The infants delivered by their mothers' prenatal OBs do not appear to be substantially healthier. They are not less likely to have low Apgar scores, or to be admitted to the NICU, or to have serious respiratory issues at birth. Those are rare outcomes. While we are leveraging large treatment differences, our sample is small for studying such rare outcomes. Using a much larger sample Card, Fenizia, and Silver (Forthcoming) finds that infants delivered at high C-section hospitals are less likely to have low Apgar scores and have no difference in NICU admission but are more likely to have respiratory infections in their first year.

\section{Discussion}

We have shown that preexisting physician-patient relationships affect treatment decisions. In this section, we discuss a few potential mechanisms.

A number of potential mechanisms are related to physician agency, a long-standing area of economic interest (Ellis and McGuire 1986; McGuire 2000). Malpractice concerns are one of the most commonly cited explanations for rising C-section rates (Currie and MacLeod 2008). Physicians may believe that patients they know and have a good rapport with will be less likely to sue after an adverse outcome and therefore practice less defensive medicine. This is the opposite of what we find. DOBs perform more C-sections and have fewer complications with their own patients.

Another possibility is that DOBs are able to exploit relationships with their patients to induce demand more effectively. They are less likely to use continuous EFM or order more supplemental tests with their own patients. Still, in this setting there is very little direct financial incentive to perform a C-section, so the primary self-interest would be to minimize effort or make the birth more convenient for the DOB. The DOB's personal opportunity cost of continuing labor is highest when the patient is near the DOB's end of shift (Chan 2018). In those cases, a completed delivery means the DOB is free to leave labor and delivery. We find that the own-patient C-section effect is unaffected by the number of other patients at the time of the birth or overall that day (Table A.12) ${ }^{16}$ Nonetheless, we cannot rule out that the lower C-section rate we observe in patients deliv16. OBs may also want to speed delivery if they are busy, but the effect is not larger during the busiest shifts. 
ered by unfamiliar DOBs arises from patients refusing to consent to $\mathrm{C}$-sections until the situation has progressed beyond the clinical gray area.

Differential reputation costs could reduce the cost of inducing demand in one's own patients. After delivering a colleague's patient, a fellow OB will get a report of the birth and may form an opinion of the appropriateness of care. If these monitoring and associated reputation concerns were responsible for the $\mathrm{C}$-section differential, OBs should be equally more likely to perform a $\mathrm{C}$-section on all of their own patients. Instead we find the differential is concentrated in the patients with whom the OB has the strongest prior relationships (Table 3).

Another potentially important mechanism is information. OBs gather relevant medical information during prenatal appointments. However, we find that the own patient effect is the same for patients with and without preexisting conditions. This is perhaps unsurprising since OBs share prenatal information and much of the information relevant to the likely success and safety of continuing with a planned vaginal delivery is only revealed as the labor progresses.

Finally, relationships per se could invoke many of the behavioral responses that humans exhibit when making personal decisions. Our evidence appears to be most consistent with a heightened concern by $\mathrm{OBs}$ to avoid perceived complications of vaginal delivery and C-sections following long labors among their own patients, leading to a lower threshold for switching to a C-section. Many of the arguments for professional objectivity are related to how physicians respond to the occurrence or prospect of adverse events, and a growing qualitative literature in patient safety has uncovered concerns about how providers process adverse events for their own patients. Termed the "second-victim phenomenon," providers whose patients experience adverse events frequently undergo anxiety and depression and may doubt their clinical abilities (Moore, Witt, and Elixhauser 2014). The likelihood of this phenomenon seems to increase in the prior relationship or social similarity between the patient and provider (Scott et al. 2009).

A natural question is whether the effects we document are likely to generalize beyond obstetrics or even beyond these practices. The practices we study deliver privately insured patients at an elite academic medical center. Their patients are slightly older and wealthier than the average person giving birth, but they are otherwise typical. Their C-sections rates are within a percentage point of 
their state average. The providers we study allow attempts at vaginal birth after prior Cesareans, a practice that varies widely across hospitals (Triebwasser et al. 2019), but the results are robust to limiting the sample to first births. Both the overall level of use of various procedures and the probability of a C-section in response to major complications and comorbidities by these OBs are comparable to the rates we observe in the National Center for Health Statistics' data on all births in US hospitals. Still, the OBs we study and the support staff they work with may be more skilled and better resourced than average. This could limit the potential for adverse infant health outcomes and surgical complications from C-sections. They could also be particularly adept at handling information transfers across providers. Information loss in hand-offs could play a larger role in settings that are not as well organized.

\section{Conclusion}

We show that physician-patient relationships have a large effect on clinical decisions. All else equal, an $\mathrm{OB}$ is $25 \%$ more likely to perform a C-section on her own patient. To achieve a similar increase in the C-section rate one would need to raise the OB's C-section fee differential by $\$ 625(150 \%$ of the average OB fee differential). ${ }^{17}$ The own-patient effect is larger than the effect of major tort reforms which have been estimated to increase the C-section rate by 5-7\% (Currie and MacLeod 2008; Shurtz 2014). One would need to more than double malpractice premiums to produce an effect of this size. ${ }^{18}$ The effect is equivalent to living 25 miles closer to a hospital with a high Csection rate (Card, Fenizia, and Silver Forthcoming), 5 miles farther than the maximum distance in that study's sample.

Our findings demonstrate, contrary to prevailing wisdom, that increasing provider continuity can increase treatment intensity. This suggests that the widespread changes in obstetrics and beyond that curtail repeated physician-patient interactions could impact treatment decisions and outcomes, even

17. A $\$ 100$ increase in the $\mathrm{C}$-section fee differential is estimated to raise the C-section rate by $4 \%$ (Alexander 2015; Gruber, Kim, and Mayzlin 1999). The Healthcare Blue Book lists the physician fees for a vaginal birth and a C-section along with associated postpartum care as $\$ 4,040$ and $\$ 4,484$, respectively.

18. Dubay, Kaestner, and Waidmann (1999) estimate that a $\$ 10,000$ malpractice premium reduction reduces the primary C-section rate by $2 \%$ for married, college educated mothers. In 2014, the average OB malpractice premium was $\$ 70,000$ (authors' calculation of the birth-weighted average malpractice premium from the Medical Liability Monitor). 
when holding the same set of providers and patients fixed. In obstetrics, the more widespread use of laborists and shared call could substantially lower C-section rates but may not reduce hospital stays by much. When OBs deliver their own patients, mothers experience fewer complications, but the injuries avoided are not sufficiently serious to shorten the hospital stay. To determine social optimality, this benefit must be weighed against the resource and long-term health costs of a substantially higher $\mathrm{C}$-section rate. Whether the changes in treatment choices induced by physicians with stronger relationships with their patients reflect a movement closer to patient preferences or whether they represent a distortion is an area of future research. 


\section{References}

Abenhaim, H. A., Benjamin, A., Koby, R. D., Kinch, R. A., \& Kramer, M. S. (2007). Comparison of Obstetric Outcomes Between On-Call and Patients' Own Obstetricians. Canadian Medical Association Journal, 177(4), 352-356.

Agha, L., Frandsen, B., \& Rebitzer, J. B. (2017). Causes and Consequences of Fragmented Care Delivery: Theory, Evidence, and Public Policy. (Working Paper No. 23078). National Bureau of Economic Research.

Alexander, D. (2015). Does Physician Pay Affect Procedure Choice and Patient Health? Evidence from Medicaid C-section Use. (Technical Report). Princeton University.

Allen, V. M., Baskett, T. F., O’Connell, C. M., McKeen, D., \& Allen, A. C. (2009). Maternal and Perinatal Outcomes With Increasing Duration of the Second Stage of Labor. Obstetrics and Gynecology, 113(6), 1248-1258.

Alpay, Z., Saed, G. M., \& Diamond, M. P. (2008). Postoperative Adhesions: From Formation to Prevention. Seminars in Reproductive Medicine, 26(04), 313-321.

American College of Obstetricians and Gynecologists. (2014). Safe Prevention of the Primary Cesarean Delivery. Obstetrics and Gynecology, 123, 693-711.

American Medical Association. (1993). Opinion 8.19 - Self-Treatment or Treatment of Immediate Family Members. AMA.

Ananth, C. V., Smulian, J. C., \& Vintzileos, A. M. (1997). The Association of Placenta Previa with History of Cesarean Delivery and Abortion: A Metaanalysis. American Journal of Obstetrics and Gynecology, 177(5), 1071-1078.

Bailit, J. L., Grobman, W. A., Rice, M. M., Wapner, R. J., Reddy, U. M., Varner, M. W., Thorp, J. M., Caritis, S. N., Iams, J. D., Saade, G., Rouse, D. J., Tolosa, J. E., Talucci, M., Zylfijaj, M., Reid, Z., Leed, R., Benson, J., Forester, S., Kitto, C., .. VanDorsten, J. (2016). Evaluation of Delivery Options for Second-Stage Events. American Journal of Obstetrics and Gynecology, 214(5), 638.e1-638.e10. 
Bandiera, O., Barankay, I., \& Rasul, I. (2009). Social Connections and Incentives in the Workplace: Evidence from Personnel Data. Econometrica, 77(4), 1047-1094.

Baskett, T. F., Allen, V. M., O’Connell, C. M., \& Allen, A. C. (2007). Fetal Trauma in Term Pregnancy. American Journal of Obstetrics and Gynecology, 197(5), 499.e1-499.e7.

Beisswanger, A. H., Stone, E. R., Hupp, J. M., \& Allgaier, L. (2003). Risk Taking in Relationships: Differences in Deciding for Oneself Versus for a Friend. Basic and Applied Social Psychology, 25(2), 121-135.

Card, D., Fenizia, A., \& Silver, D. (Forthcoming). The Health Impacts of Hospital Delivery Practices. American Economic Journal: Economic Policy.

Caruso, E. M. (2008). Use of Experienced Retrieval Ease in Self and Social Judgments. Journal of Experimental Social Psychology, 44(1), 148-155.

Chan, D. C. (2018). The Efficiency of Slacking Off: Evidence from the Emergency Department. Econometrica, 86(3), 997-1030.

Chan, D. C., Gentzkow, M., \& Yu, C. (2022). Selection with Variation in Diagnostic Skill: Evidence from Radiologists. The Quarterly Journal of Economics.

Chandra, S., Wright, S. M., \& Howell, E. E. (2012). The Creating Incentives and Continuity Leading to Efficiency Staffing Model: A Quality Improvement Initiative in Hospital Medicine. Mayo Clinic Proceedings, 87(4), 364-371.

Currie, J., \& MacLeod, W. B. (2008). First Do No Harm? Tort Reform and Birth Outcomes. The Quarterly Journal of Economics, 123(2), 795-830.

Currie, J., \& MacLeod, W. B. (2013). Diagnosis and Unnecessary Procedure Use: Evidence from C-section. (Working Paper No. 18977). National Bureau of Economic Research.

Dahl, G. B., \& Forbes, S. J. (2016). Doctor Switching Costs in Health Insurance. (Technical Report). Weatherhead School of Management.

Dubay, L., Kaestner, R., \& Waidmann, T. (1999). The Impact of Malpractice Fears on Cesarean Section Rates. Journal of Health Economics, 18(4), 491-522.

Ellis, R. P., \& McGuire, T. G. (1986). Provider Behavior Under Prospective Reimbursement: Cost Sharing and Supply. Journal of Health Economics, 5(2), 129-151. 
Epstein, A. J., \& Nicholson, S. (2009). The Formation and Evolution of Physician Treatment Styles: An Application to Cesarean Sections. Journal of Health Economics, 28(6), 1126-1140.

Fenner, D. E., Genberg, B., Brahma, P., Marek, L., \& DeLancey, J. O. (2003). Fecal and Urinary Incontinence After Vaginal Delivery with Anal Sphincter Disruption in an Obstetrics Unit in the United States. American Journal of Obstetrics and Gynecology, 189(6), 1543-1549.

Gruber, J., Kim, J., \& Mayzlin, D. (1999). Physician Fees and Procedure Intensity: The Case of Cesarean Delivery. Journal of Health Economics, 18(4), 473-490.

Hall, M. H., \& Bewley, S. (1999). Maternal Mortality and Mode of Delivery. The Lancet, 354(9180), 776.

Halla, M., Mayr, H., Pruckner, G. J., \& García-Gómez, P. (2020). Cutting Fertility? Effects of Cesarean Deliveries on Subsequent Fertility and Maternal Labor Supply. Journal of Health Economics, 72, 102325.

Hoffman, E., McCabe, K., \& Smith, V. L. (1996). Social Distance and Other-Regarding Behavior in Dictator Games. The American Economic Review, 86(3), 653-660.

Hsee, C. K., \& Weber, E. U. (1997). A Fundamental Prediction Error: Self-Others Discrepancies in Risk Preference. Journal of Experimental Psychology: General, 126(1), 45.

Iriye, B. K., Huang, W. H., Condon, J., Hancock, L., Hancock, J. K., Ghamsary, M., \& Garite, T. J. (2013). Implementation of a Laborist Program and Evaluation of the Effect Upon Cesarean Delivery. American Journal of Obstetrics and Gynecology, 209(3), 251-e1.

Kammerer-Doak, D., \& Rogers, R. G. (2008). Female Sexual Function and Dysfunction. Obstetrics and Gynecology Clinics of North America, 35(2), 169-183.

Kim, S. S., Kaplowitz, S., \& Johnston, M. V. (2004). The Effects of Physician Empathy on Patient Satisfaction and Compliance. Evaluation and The Health Professions, 27(3), 237-251.

Levinson, W., Roter, D. L., Mullooly, J. P., Dull, V. T., \& Frankel, R. M. (1997). Physician-Patient Communication: The Relationship with Malpractice Claims Among Primary Care Physicians and Surgeons. Journal of the American Medical Association, 277(7), 553-559.

Loewenstein, G. (2000). Emotions in Economic Theory and Economic Behavior. American Economic Review, 90(2), 426-432. 
Loewenstein, G. (2005). Hot-Cold Empathy Gaps and Medical Decision Making. Health Psychology, 24(4S), S49-S56.

Lydon-Rochelle, M., Holt, V. L., Martin, D. P., \& Easterling, T. R. (2000). Association Between Method of Delivery and Maternal Rehospitalization. Journal of the American Medical Association, 283(18), 2411-2416.

Mager, W. M., \& Andrykowski, M. A. (2002). Communication in the Cancer 'Bad News' Consultation: Patient Perceptions and Psychological Adjustment. Psycho-Oncology, 11(1), 3546.

McGuire, T. G. (2000). Physician Agency. In A. J. Culyer \& J. P. Newhouse (Eds.), Handbook of Health Economics (pp. 461-536). Elsevier.

Medical Liability Monitor. (2014). Annual Rate Survey.

Meltzer, D., Manning, W. G., Morrison, J., Shah, M. N., Jin, L., Guth, T., \& Levinson, W. (2002). Effects of Physician Experience on Costs and Outcomes on an Academic General Medicine Service: Results of a Trial of Hospitalists. Annals of Internal Medicine, 137(11), 866-874.

Moore, J. E., Witt, W. P., \& Elixhauser, A. (2014). Complicating Conditions Associated with Childbirth, by Delivery Method and Payer, 2011. (Statistical Brief 173). Rockville, MD: Agency for Healthcare Research; Quality.

Nijagal, M. A., Kuppermann, M., Nakagawa, S., \& Cheng, Y. (2015). Two Practice Models in One Labor and Delivery Unit: Association with Cesarean Delivery Rates. American Journal of Obstetrics and Gynecology, 212(4), 491-e1.

Norberg, K., \& Pantano, J. (2016). Cesarean Sections and Subsequent Fertility. Journal of Population Economics, 29(1), 5-37.

Pergialiotis, V., Bellos, I., Antsaklis, A., Papapanagiotou, A., Loutradis, D., \& Daskalakis, G. (2020). Maternal and Neonatal Outcomes Following a Prolonged Second Stage of Labor: A MetaAnalysis of Observational Studies. European Journal of Obstetrics \& Gynecology and Reproductive Biology, 252, 62-69.

Polman, E. (2012). Effects of Self-Other Decision Making on Regulatory Focus and Choice Overload. Journal of Personality and Social Psychology, 102(5), 980. 
Romano, M. J., Segal, J. B., \& Pollack, C. E. (2015). The Association Between Continuity of Care and the Overuse of Medical Procedures. Journal of the American Medical Association Internal Medicine, 175(7), 1148-1154.

Sabety, A. (2022). The Value of Relationships in Healthcare, Unpublished.

Scott, S. D., Hirschinger, L. E., Cox, K. R., McCoig, M., Brandt, J., \& Hall, L. W. (2009). The Natural History of Recovery for the Healthcare Provider "Second Victim" After Adverse Patient Events. BMJ Quality \& Safety, 18(5), 325-330.

Shurtz, I. (2014). Malpractice Law, Physicians' Financial Incentives, and Medical Treatment: How Do They Interact? The Journal of Law and Economics, 57(1), 1-29.

Skinner, J. S., Staiger, D. O., \& Fisher, E. S. (2006). Is Technological Change In Medicine Always Worth It? The Case Of Acute Myocardial Infarction: Waste and Inefficiency Are Not Inevitable By-Products of Technological Growth. Health Affairs, 25(Suppl1), W34-W47.

Srinivas, S. K., Shocksnider, J., Caldwell, D., \& Lorch, S. (2012). Laborist Model of Care: Who is Using It? The Journal of Maternal-Fetal \& Neonatal Medicine, 25(3), 257-260.

Triebwasser, J. E., Kamdar, N. S., Langen, E. S., Moniz, M. H., Basu, T., Syrjamaki, J., Thomason, A. C., Smith, R. D., \& Morgan, D. M. (2019). Hospital Contribution to Variation in Rates of Vaginal Birth after Cesarean. Journal of Perinatology: Official Journal of the California Perinatal Association, 39(7), 904-910.

Trope, Y., \& Liberman, N. (2010). Construal-Level Theory of Psychological Distance. Psychological Review, 117(2), 440-463.

Wachter, R. M., \& Goldman, L. (1996). The Emerging Role of "Hospitalists" in the American Health Care System. New England Journal of Medicine, 335(7), 514-517.

Wachter, R. M., \& Goldman, L. (2002). The Hospitalist Movement 5 Years Later. Journal of the American Medical Association, 287(4), 487-494.

Wachter, R. M., Katz, P., Showstack, J., Bindman, A. B., \& Goldman, L. (1998). Reorganizing an Academic Medical Service: Impact on Cost, Quality, Patient Satisfaction, and Education. Journal of the American Medical Association, 279(19), 1560-1565. 
Wasson, J. H., Sauvigne, A. E., Mogielnicki, R. P., Frey, W. G., Sox, C. H., Gaudette, C., \& Rockwell, A. (1984). Continuity of Outpatient Medical Care in Elderly Men: A Randomized Trial. Journal of the American Medical Association, 252(17), 2413-2417. 
Figure 1 Mean C-section Rate by Number of Visits for Own and Others' Patients

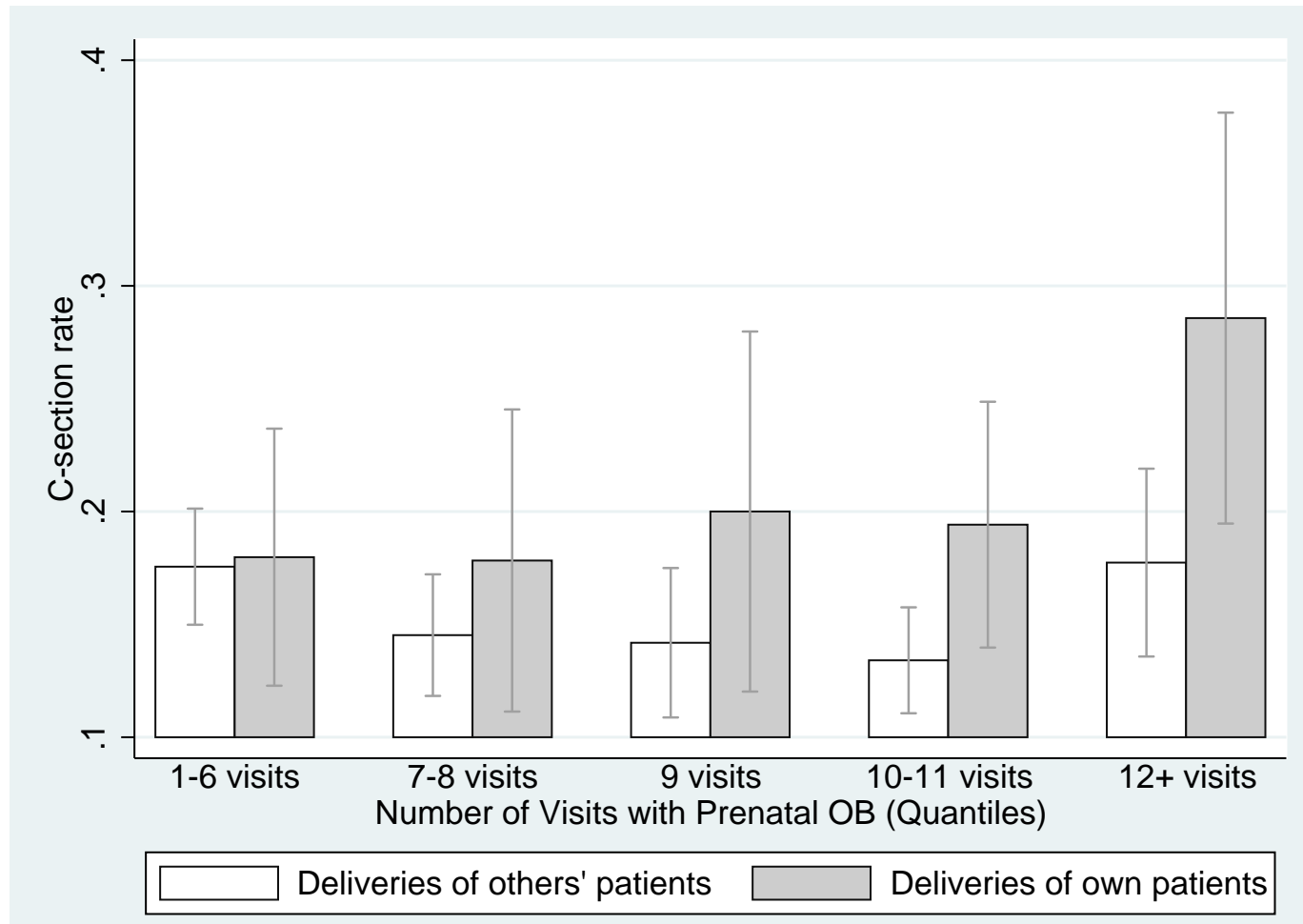

Bars plot the average $\mathrm{C}$-section rate of patients by the quintile of the number of prenatal visits with the prenatal OB. Horizontal brackets display 95\% confidence intervals. "Own patients" are deliveries in which the delivering OB (DOB) and primary prenatal OB are the same physician. "Others' patients" are deliveries in which the DOB and primary prenatal $\mathrm{OB}$ are different physicians. 
TABle 1 PATIENT CharaCteristics (MEANS)

\begin{tabular}{|c|c|c|c|c|c|}
\hline & Own Patient & Other OB's Patient & & Own Patient & Other OB's Patient \\
\hline \multicolumn{3}{|c|}{ Risk Factors (\%): } & \multicolumn{3}{|c|}{ Risk Factors Cont. (\%): } \\
\hline Nulliparous birth & 48.9 & 54.2 & Diabetes & 3.52 & 3.51 \\
\hline Previous C-section or scar & 9.14 & 6.57 & Hypertension & 3.09 & 3.35 \\
\hline Malposition or malpresented & 6.19 & 5.01 & Asthma & $2.11^{+}$ & $3.32^{+}$ \\
\hline Premature rupture of membranes & 5.34 & 6.7 & Thyroid & 3.94 & 4.2 \\
\hline Under 37 weeks gestation & 5.20 & 6.96 & Heart & 0.985 & 1.04 \\
\hline Over 41 weeks gestation & 3.8 & 2.73 & Lung & 2.53 & 3.45 \\
\hline Gestational age (weeks) & 39.3 & 39.2 & \multicolumn{3}{|c|}{ Socioeconomic Status (\%): } \\
\hline Obesity and morbid obesity & 0.703 & 0.651 & Age (years) & 33.1 & 33 \\
\hline Clots and clotting disorders & 0.422 & 0.488 & Age $35-39$ & 28.6 & 27.5 \\
\hline Anemia & 0.563 & 0.878 & Over 40 & 5.06 & 4.33 \\
\hline Short or incompetent cervix & 0.703 & 0.553 & \multicolumn{3}{|l|}{ Mother's Race: } \\
\hline Placental condition & 2.39 & 1.95 & White & 68.6 & 67.6 \\
\hline Physical obstruction & 1.27 & 0.911 & Black & 7.31 & 8.33 \\
\hline Intrauterine growth restriction & 0.563 & 0.748 & Hispanic & 5.06 & 5.5 \\
\hline Oligohydramnios & 1.27 & 0.976 & Other & 19 & 18.5 \\
\hline Pelvic anomaly & 3.66 & 3.42 & Married & 81.4 & 80.8 \\
\hline Placenta previa & 0.844 & 0.976 & Zip code income & 33,437 & 33,256 \\
\hline Isoimmunity & 3.66 & 2.37 & & & \\
\hline Tumors & 1.41 & 1.72 & \multicolumn{3}{|c|}{ Predicted Probabilities (\%): } \\
\hline Other rare conditions ${ }^{\dagger}$ & 0.281 & 0.39 & C-section & 17 & 16.1 \\
\hline Birth weight $(\text { grams })^{\dagger \dagger}$ & 3,361 & 3,355 & Laceration & 55.6 & 56.0 \\
\hline Observations & 711 & 3,074 & Observations & 711 & 3,074 \\
\hline
\end{tabular}

Notes: Means for the main estimation sample described in Section III.B. Standard Deviations are omitted as they are uninformative for binary variables.

${ }^{\dagger}$ Other rare conditions include renal failure, epilepsy, lupus, vasa previa, and deep transverse arrest. ${ }^{\dagger \dagger}$ Not available for 2012 . ${ }^{\dagger \dagger}$ Predicted probabilities from logistic regression using all of the socioeconomic variables and risk factors listed above. 
Table 2 Prenatal Care and Treatments of OBs' Own Patients and Other OBs' Patients

\begin{tabular}{|c|c|c|c|c|}
\hline \multirow[b]{3}{*}{$\underline{\text { Prenatal Care: }}$} & \multicolumn{2}{|c|}{ Own Patient } & \multicolumn{2}{|c|}{ Other OB's Patien } \\
\hline & Mean & Std. Dev. & Mean & Std. Dev. \\
\hline & & & & \\
\hline Percent of visits with delivering OB & 77.1 & [18.3] & 4.28 & {$[8.01]$} \\
\hline Percent of visits with prenatal OB & 77.2 & [18.1] & 74.7 & {$[18.7]$} \\
\hline Percent of visits with second prenatal $\mathrm{OB}^{\dagger}$ & 23.2 & {$[26.1]$} & 22.9 & {$[24.1]$} \\
\hline Number of prenatal visits & 11.4 & [2.93] & 11.5 & [3.01] \\
\hline \multicolumn{5}{|l|}{ Treatments in labor \& delivery $(\%)$ : } \\
\hline C-section & 20.1 & {$[40.1]$} & 15.4 & {$[36.1]$} \\
\hline Assisted vaginal delivery & 7.03 & [25.6] & 9.92 & [29.9] \\
\hline Total procedures (procedures) & 12.3 & [4.69] & 12.8 & [5.23] \\
\hline Epidural anesthesia & 92.4 & {$[26.5]$} & 91.6 & {$[27.7]$} \\
\hline Augmented labor & 61.2 & {$[48.8]$} & 59.2 & {$[49.2]$} \\
\hline Total tests (tests) & 7.77 & {$[3.64]$} & 8.07 & {$[4.19]$} \\
\hline No continuous EFM & 12.7 & {$[33.3]$} & 8.43 & {$[27.8]$} \\
\hline Ultrasound & 2.53 & {$[15.7]$} & 3.9 & {$[19.4]$} \\
\hline Observations & 711 & & 3,074 & \\
\hline
\end{tabular}

Notes: Means and standard deviations are calculated from the main estimation sample as described in Section III.B.

$\dagger$ The second prenatal provider is the second most frequently seen OB during prenatal care. 
Table 3 The Physician-Patient Relationship and C-Section Decisions

\begin{tabular}{|c|c|c|c|c|c|}
\hline Panel A & (1) & (2) & (3) & (4) & (5) \\
\hline Own Patient & $\begin{array}{c}0.039 \\
{[0.013]}\end{array}$ & $\begin{array}{c}0.040 \\
{[0.011]}\end{array}$ & & & $\begin{array}{c}0.006 \\
{[0.018]}\end{array}$ \\
\hline First Prenatal OB is DOB & & & $\begin{array}{c}0.034 \\
{[0.011]}\end{array}$ & & \\
\hline OB's Share of Prenatal Visits & & & & $\begin{array}{c}0.059 \\
{[0.014]}\end{array}$ & \\
\hline Own Patient $\times$ Strong Relationship & & & & & $\begin{array}{c}0.067 \\
{[0.023]}\end{array}$ \\
\hline Strong Relationship & & & & & $\begin{array}{c}-0.011 \\
{[0.012]}\end{array}$ \\
\hline Fixed Effects? & & Yes & Yes & Yes & Yes \\
\hline Observations & 3,785 & 3,785 & 3,785 & 3,785 & 3,375 \\
\hline Adjusted $\mathrm{R}^{2}$ & 0.27 & 0.28 & 0.28 & 0.28 & 0.29 \\
\hline Panel B: Subsamples & (1) & (2) & (3) & (4) & (5) \\
\hline Own Patient & $\begin{array}{c}0.044 \\
{[0.020]}\end{array}$ & $\begin{array}{c}0.040 \\
{[0.030]}\end{array}$ & $\begin{array}{c}0.049 \\
{[0.013]}\end{array}$ & $\begin{array}{c}0.042 \\
{[0.014]}\end{array}$ & $\begin{array}{c}0.033 \\
{[0.012]}\end{array}$ \\
\hline Fixed Effects? & Yes & Yes & Yes & Yes & Yes \\
\hline Sample & $\begin{array}{l}\text { First } \\
\text { Births }\end{array}$ & $\begin{array}{c}\text { Low Risk } \\
\text { First Births }\end{array}$ & $\begin{array}{c}\text { No } \\
\text { Preterm }\end{array}$ & $\begin{array}{l}\text { No Contra- } \\
\text { indications }\end{array}$ & $\begin{array}{c}\text { None Over } \\
41 \text { Weeks }\end{array}$ \\
\hline Observations & 2015 & 1487 & 3534 & 3587 & 3674 \\
\hline Adjusted $\mathrm{R}^{2}$ & 0.25 & 0.12 & 0.25 & 0.19 & 0.30 \\
\hline
\end{tabular}

Notes: Table displays OLS estimates of Equation (1). Own patient is an indicator the DOB was the patient's primary prenatal provider. OB's share is the share of the patient's prenatal visits provided by the DOB. Strong relationship is an indicator the patient had over $79 \%$ of prenatal visits with her primary prenatal OB (the median). All regressions contain the full set of socio-economic and clinical variables summarized in Table 1. Prenatal provider and DOB fixed effects are included as indicated. Standard errors, clustered by the DOB, are in brackets. 
TABle 4 Additional Treatment Decisions And Outcomes

\begin{tabular}{|c|c|c|c|c|}
\hline & (1) & (2) & (3) & (4) \\
\hline Panel A: Other Treatment Decsions & $\begin{array}{c}\text { Length of } \\
\text { Second Stage }\end{array}$ & $\begin{array}{l}\text { Assisted } \\
\text { Delivery }\end{array}$ & $\begin{array}{c}\text { No Cont. } \\
\text { EFM }\end{array}$ & $\begin{array}{l}\text { Log Length } \\
\text { Of Stay }{ }^{\dagger} \dagger\end{array}$ \\
\hline Own Patient & $\begin{array}{c}-0.11 \\
{[0.051]}\end{array}$ & $\begin{array}{c}-0.025 \\
{[0.0100]}\end{array}$ & $\begin{array}{c}0.035 \\
{[0.0078]}\end{array}$ & $\begin{array}{c}0.020 \\
{[0.0076]}\end{array}$ \\
\hline $\begin{array}{l}\text { Observations } \\
\text { Adjusted } \mathrm{R}^{2} \\
\text { Dependent Variable Mean }\end{array}$ & $\begin{array}{c}3,205 \\
0.16 \\
0.968\end{array}$ & $\begin{array}{c}3,779 \\
0.13 \\
0.0938\end{array}$ & $\begin{array}{c}3,749 \\
0.043 \\
0.0922\end{array}$ & $\begin{array}{c}3,779 \\
0.23 \\
0.845\end{array}$ \\
\hline Panel B: Maternal Outcomes & $\begin{array}{l}\text { Laceration } \\
\text { Repair }\end{array}$ & $\begin{array}{c}\text { Any } \\
\text { Complicaiton }\end{array}$ & Fever & Trauma \\
\hline Own Patient & $\begin{array}{c}-0.044 \\
{[0.015]}\end{array}$ & $\begin{array}{c}-0.032 \\
{[0.0012]}\end{array}$ & $\begin{array}{c}-0.019 \\
{[0.0095]}\end{array}$ & $\begin{array}{c}-0.012 \\
{[0.0059]}\end{array}$ \\
\hline $\begin{array}{l}\text { Observations } \\
\text { Adjusted } \mathrm{R}^{2} \\
\text { Dependent Variable Mean }\end{array}$ & $\begin{array}{c}3,785 \\
0.12 \\
0.683\end{array}$ & $\begin{array}{l}3,782 \\
0.067 \\
0.172\end{array}$ & $\begin{array}{c}3,752 \\
0.15 \\
0.0741\end{array}$ & $\begin{array}{c}3,589 \\
0.078 \\
0.0279\end{array}$ \\
\hline Panel C: Infant Outcomes & $\begin{array}{c}\text { Any } \\
\text { Respiratory }\end{array}$ & $\begin{array}{c}\text { Serious } \\
\text { Respiratory }\end{array}$ & $\begin{array}{l}\text { Low Apgar } \\
\text { Score }^{\dagger \dagger \dagger}\end{array}$ & $\begin{array}{c}\text { NICU } \\
\text { Admission }\end{array}$ \\
\hline Own Patient & $\begin{array}{c}-0.017 \\
{[0.012]}\end{array}$ & $\begin{array}{l}-0.0093 \\
{[0.0070]}\end{array}$ & $\begin{array}{c}0.012 \\
{[0.0089]}\end{array}$ & $\begin{array}{l}-0.0029 \\
{[0.0078]}\end{array}$ \\
\hline $\begin{array}{l}\text { Observations } \\
\text { Adjusted } \mathrm{R}^{2} \\
\text { Dependent Variable Mean }\end{array}$ & $\begin{array}{c}3,180 \\
0.12 \\
0.0962\end{array}$ & $\begin{array}{c}3,065 \\
0.25 \\
0.0388\end{array}$ & $\begin{array}{c}3,150 \\
0.19 \\
0.0511\end{array}$ & $\begin{array}{c}3,160 \\
0.26 \\
0.0570\end{array}$ \\
\hline
\end{tabular}

Notes: All regressions contain the full set of socio-economic and clinical variables summarized in Table 1 along with prenatal provider and DOB fixed effects. Standard errors, clustered by the DOB, are in brackets. Average marginal effects from logistic regressions of $y_{i}=1\left(\alpha \mathrm{Own} i+\mathbf{X}_{i}^{\prime} \beta+\zeta_{j(i)}+\eta_{p(i)}>\varepsilon_{i}\right)$ are displayed for all binary outcomes. Coefficients from an analagous OLS regression are displayed for the others (i.e. length of the second stage and log length of stay). Own patient is an indicator the DOB was the patient's primary prenatal provider. Panels B and C: Estimates for first births and estimates that control for birth method (C-section and assisted vaginal delivery) can be found Table A.7, and Table A.8.

$\dagger$ The length of the second stage of labor is measured in hours. $\dagger \dagger$ Log of maternal length of stay measured as time from admission to discharge. $\dagger \dagger \dagger$ Low Apgar is an indicator the infant had an Apgar score below 7. 
ApPEndiX - Supplementary Figures And TABles, NOT FOR Publication 
FIGURE A.1 Growth of Hospitalists in the United States

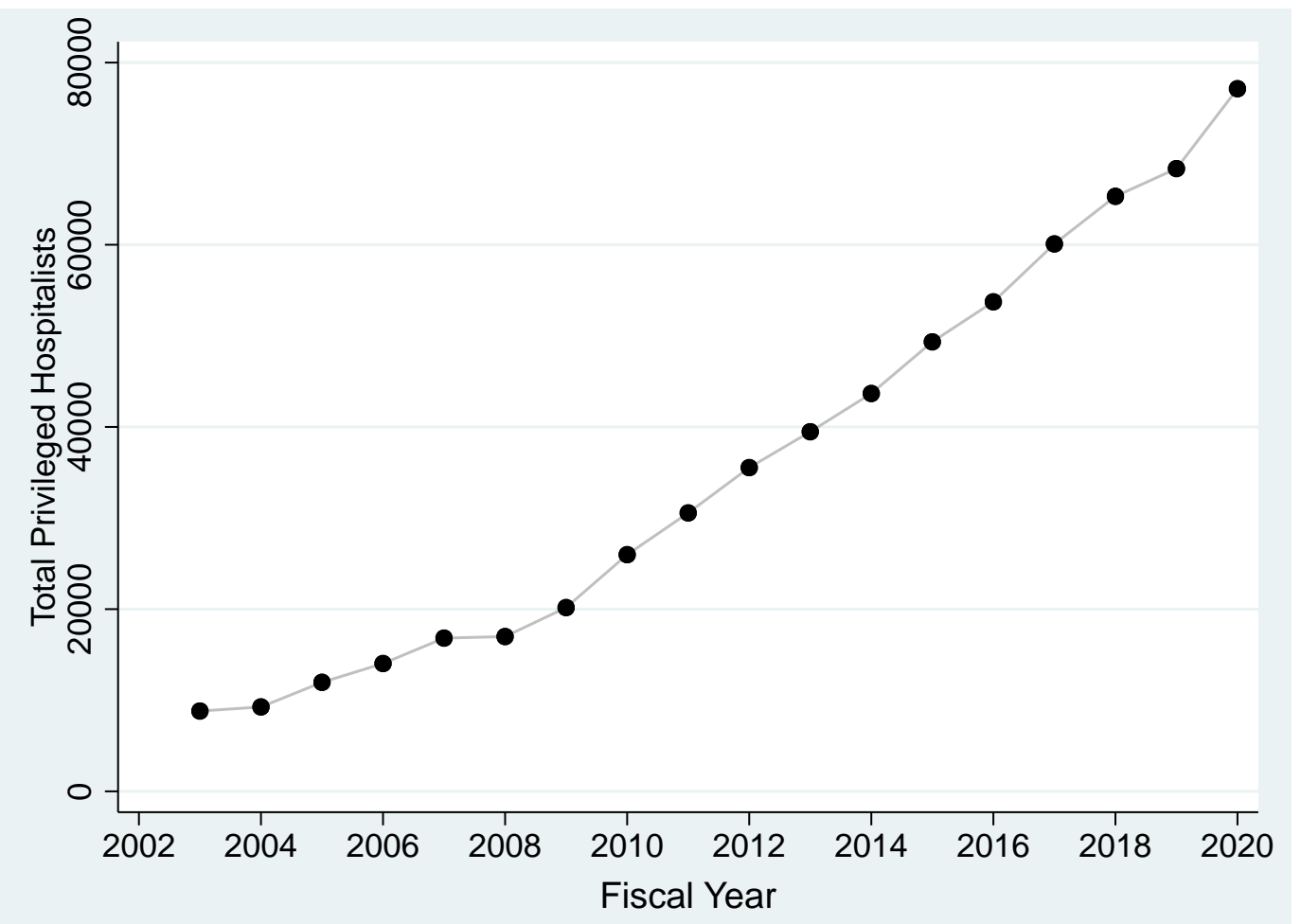

Each dot represents the number of privledged hospitalists in the US in each year from the AHA Annual Survey. 2002 is the first survey year the AHA included questions about hospitalists. The sample is restricted to those hospitals present in all survey waves. The effect of this restriction is negligible. The annual growth rate is $13.6 \%$ in this sample, compared with $14 \%$ in the full unbalanced sample. 
Figure A.2 Mean C-section Rate by Fraction of Visits for Own and Others' Patients

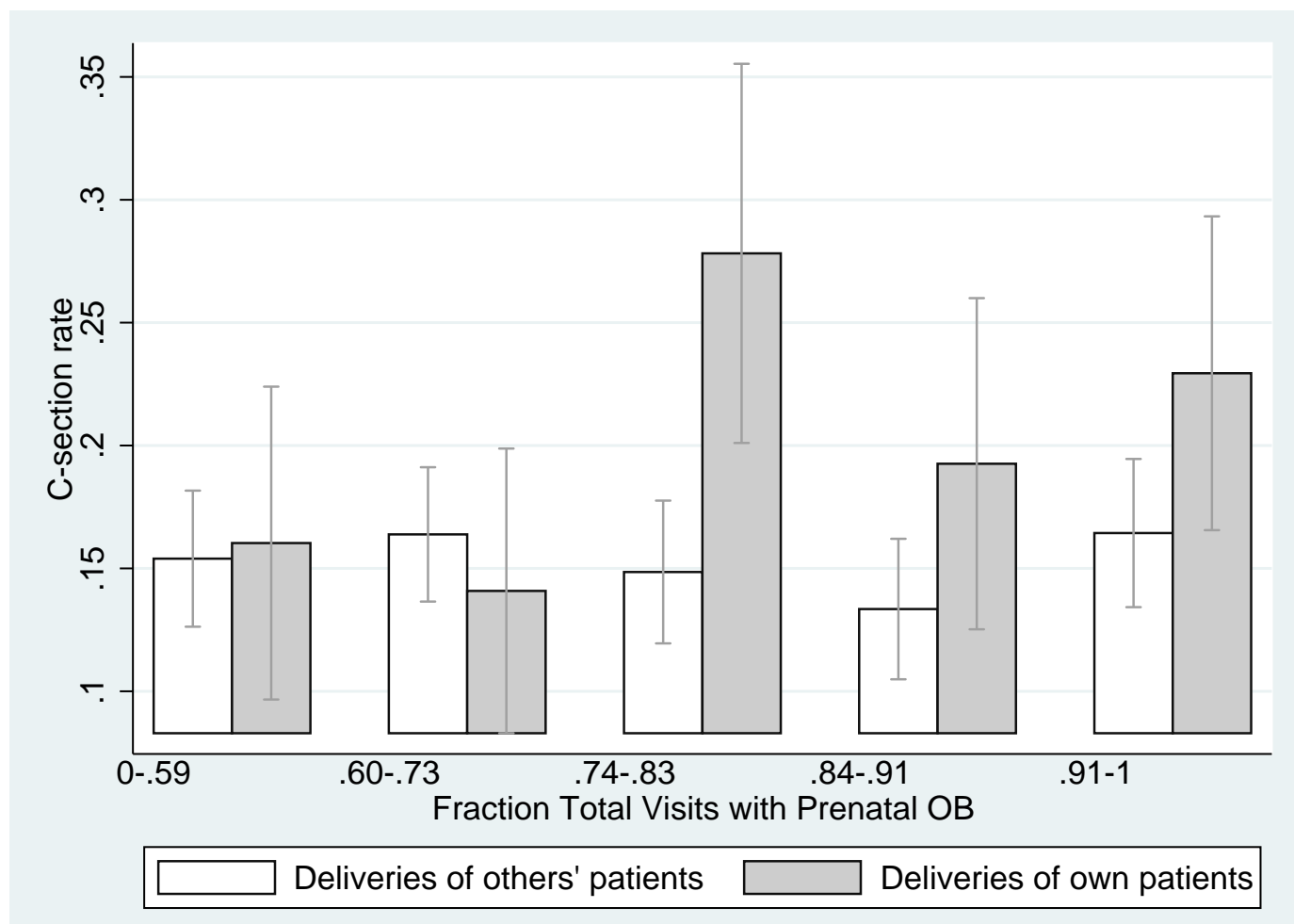

Bars plot the average C-section rate of patients by the quintile of the share of all prenatal visits that occured with the primary prenatal OB. Horizontal brackets display 95\% confidence intervals. "Own patients" are deliveries in which the delivering $\mathrm{OB}$ (DOB) and primary prenatal OB are the same physician. "Others' patients" are deliveries in which the DOB and primary prenatal OB are different physicians. 
FIGURE A.3 Number of Visits with Delivering OB During Pregnancy

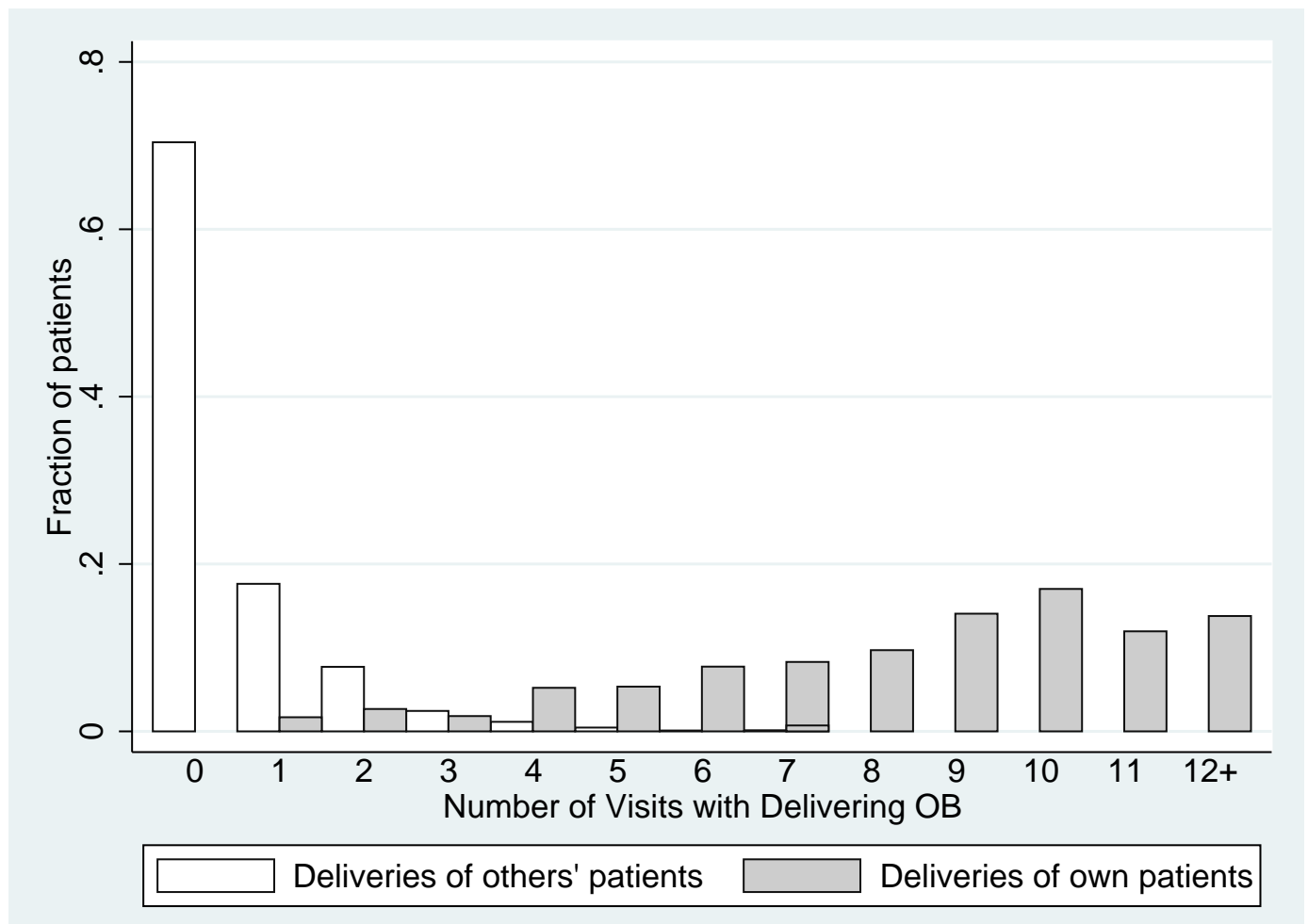

The height of each bar represents the fraction of patients with the number of prenatal visits with the delivering OB (DOB) specified on the $x$-axis. "Deliveries of own patients" are deliveries where the prenatal OB and DOB are the same physician. "Deliveries of others' patients" are deliveries in which the DOB is not the primary prenatal OB. 


\section{Table A.1 The Physician-Patient Relationship and C-SeCtion DECISIONS - \\ FULl SET OF COEFFICIENTS}

\begin{tabular}{|c|c|c|c|c|c|c|}
\hline & $(1)$ & (2) & (3) & (4) & $(5)$ & (6) \\
\hline \multirow[t]{2}{*}{ Own Patient } & 0.048 & 0.039 & 0.040 & & & \\
\hline & {$[0.017]$} & {$[0.013]$} & [0.011] & & & \\
\hline \multirow[t]{2}{*}{ OB's Share of Prenatal Visits } & & & & 0.066 & 0.056 & 0.059 \\
\hline & & & & {$[0.019]$} & {$[0.017]$} & {$[0.014]$} \\
\hline \multirow[t]{2}{*}{ Maternal Age } & & 0.0030 & 0.0028 & & 0.0030 & 0.0027 \\
\hline & & {$[0.0021]$} & {$[0.0020]$} & & {$[0.0021]$} & [0.0020] \\
\hline \multirow[t]{2}{*}{ Age $35-39$} & & 0.020 & 0.020 & & 0.020 & 0.020 \\
\hline & & {$[0.015]$} & [0.016] & & {$[0.015]$} & {$[0.016]$} \\
\hline \multirow[t]{2}{*}{ Over 40} & & 0.054 & 0.054 & & 0.054 & 0.054 \\
\hline & & {$[0.034]$} & {$[0.033]$} & & [0.035] & [0.032] \\
\hline \multirow[t]{2}{*}{ Black } & & 0.040 & 0.036 & & 0.039 & 0.035 \\
\hline & & {$[0.023]$} & {$[0.022]$} & & {$[0.023]$} & [0.022] \\
\hline \multirow[t]{2}{*}{ Hispanic } & & 0.054 & 0.052 & & 0.054 & 0.052 \\
\hline & & {$[0.032]$} & [0.031] & & [0.032] & [0.031] \\
\hline \multirow[t]{2}{*}{ Other race } & & -0.00073 & -0.0046 & & -0.00098 & -0.0049 \\
\hline & & {$[0.014]$} & [0.014] & & {$[0.014]$} & {$[0.014]$} \\
\hline \multirow[t]{2}{*}{ Married } & & 0.0041 & 0.0024 & & 0.0040 & 0.0023 \\
\hline & & {$[0.0098]$} & {$[0.0090]$} & & {$[0.0098]$} & [0.0089] \\
\hline \multirow[t]{2}{*}{ Per capita income } & & -0.036 & -0.038 & & -0.036 & -0.038 \\
\hline & & [0.013] & [0.015] & & {$[0.013]$} & {$[0.015]$} \\
\hline \multirow[t]{2}{*}{ Nulliparous birth } & & 0.14 & 0.14 & & 0.14 & 0.14 \\
\hline & & {$[0.016]$} & [0.016] & & {$[0.016]$} & {$[0.016]$} \\
\hline \multirow[t]{2}{*}{ Previous C-section or scar } & & 0.33 & 0.34 & & 0.33 & 0.34 \\
\hline & & {$[0.031]$} & [0.029] & & {$[0.031]$} & {$[0.030]$} \\
\hline \multirow[t]{2}{*}{ Malposition } & & 0.44 & 0.44 & & 0.44 & 0.44 \\
\hline & & {$[0.084]$} & [0.087] & & {$[0.084]$} & {$[0.086]$} \\
\hline \multirow[t]{2}{*}{ Premature rupture of membranes } & & 0.024 & 0.022 & & 0.025 & 0.022 \\
\hline & & {$[0.021]$} & {$[0.022]$} & & {$[0.021]$} & {$[0.022]$} \\
\hline \multirow[t]{2}{*}{ Under 37 weeks gestation } & & 0.035 & 0.033 & & 0.035 & 0.033 \\
\hline & & [0.019] & {$[0.021]$} & & [0.019] & [0.021] \\
\hline \multirow[t]{2}{*}{ Over 41 weeks gestation } & & 0.12 & 0.12 & & 0.12 & 0.12 \\
\hline & & [0.035] & [0.034] & & [0.035] & [0.033] \\
\hline \multirow[t]{2}{*}{ Gestational age } & & 0.0040 & 0.0037 & & 0.0040 & 0.0037 \\
\hline & & [0.0035] & {$[0.0038]$} & & [0.0035] & [0.0037] \\
\hline \multirow[t]{2}{*}{ Diabetes } & & 0.018 & 0.014 & & 0.018 & 0.014 \\
\hline & & [0.029] & [0.029] & & {$[0.030]$} & {$[0.029]$} \\
\hline
\end{tabular}


Table A.1 - Continued from previous page

\begin{tabular}{|c|c|c|c|c|c|c|}
\hline & (1) & (2) & (3) & (4) & (5) & (6) \\
\hline \multirow[t]{2}{*}{ Hypertension } & & 0.24 & 0.23 & & 0.24 & 0.23 \\
\hline & & {$[0.031]$} & {$[0.030]$} & & {$[0.030]$} & {$[0.029]$} \\
\hline \multirow[t]{2}{*}{ Asthma } & & -0.29 & -0.31 & & -0.30 & -0.31 \\
\hline & & {$[0.16]$} & {$[0.15]$} & & {$[0.16]$} & {$[0.15]$} \\
\hline \multirow[t]{2}{*}{ Thyroid } & & -0.020 & -0.021 & & -0.019 & -0.021 \\
\hline & & {$[0.018]$} & {$[0.019]$} & & {$[0.018]$} & {$[0.019]$} \\
\hline \multirow[t]{2}{*}{ Lung } & & 0.32 & 0.34 & & 0.33 & 0.34 \\
\hline & & {$[0.17]$} & {$[0.16]$} & & {$[0.17]$} & {$[0.16]$} \\
\hline \multirow[t]{2}{*}{ Other pre-existing condition } & & 0.080 & 0.081 & & 0.079 & 0.080 \\
\hline & & {$[0.026]$} & {$[0.025]$} & & {$[0.026]$} & {$[0.025]$} \\
\hline \multirow[t]{2}{*}{ Placenta previa } & & 0.26 & 0.28 & & 0.26 & 0.28 \\
\hline & & {$[0.079]$} & {$[0.074]$} & & {$[0.078]$} & {$[0.074]$} \\
\hline \multirow[t]{2}{*}{ Isoimmunity } & & -0.039 & -0.037 & & -0.038 & -0.037 \\
\hline & & {$[0.022]$} & {$[0.022]$} & & {$[0.022]$} & {$[0.022]$} \\
\hline \multirow[t]{2}{*}{ Oligohydramnios } & & 0.22 & 0.22 & & 0.22 & 0.22 \\
\hline & & [0.069] & [0.068] & & [0.069] & {$[0.068]$} \\
\hline \multirow[t]{2}{*}{ Pelvic anomaly } & & 0.18 & 0.18 & & 0.18 & 0.19 \\
\hline & & {$[0.049]$} & {$[0.051]$} & & {$[0.050]$} & {$[0.051]$} \\
\hline \multirow[t]{2}{*}{ Placental condition } & & 0.14 & 0.14 & & 0.14 & 0.14 \\
\hline & & {$[0.060]$} & {$[0.059]$} & & {$[0.061]$} & {$[0.059]$} \\
\hline \multirow[t]{2}{*}{ Physical obstruction } & & 0.35 & 0.35 & & 0.34 & 0.35 \\
\hline & & {$[0.079]$} & {$[0.080]$} & & {$[0.079]$} & {$[0.081]$} \\
\hline \multirow[t]{2}{*}{ Tumors } & & 0.15 & 0.14 & & 0.15 & 0.14 \\
\hline & & {$[0.078]$} & {$[0.075]$} & & {$[0.079]$} & {$[0.075]$} \\
\hline Controls? & & Yes & Yes & & Yes & Yes \\
\hline Fixed Effects? & & & Yes & & & Yes \\
\hline Observations & 3,785 & 3,785 & 3,785 & 3,785 & 3,785 & 3,785 \\
\hline Adjusted $\mathrm{R}^{2}$ & 0.0023 & 0.28 & 0.29 & 0.0027 & 0.28 & 0.29 \\
\hline
\end{tabular}

Notes: Table reproduces Table 3, displaying the coefficients and standard errors for all controls. Own patient is an indicator the delivering OB was the patient's primary prenatal provider. OB's share is the share of the patient's prenatal visits provided by the delivering OB. Prenatal provider and delivering OB fixed effects are included as indicated. Standard errors, clustered by the delivering OB, are in brackets. 
Table A.2 The Physician-Patient Relationship and C-Section Decisions ROBUSTNESS

\begin{tabular}{|c|c|c|}
\hline & Observations & $\begin{array}{l}\text { Own Patient } \\
\text { Coefficient }\end{array}$ \\
\hline \multicolumn{3}{|l|}{ Baseline: } \\
\hline Baseline (all births) & 3,785 & $\begin{array}{c}0.040 \\
{[0.011]}\end{array}$ \\
\hline $\begin{array}{l}\text { Alternate defintion of prenatal OB } \\
\text { (First visit) }\end{array}$ & 3,785 & $\begin{array}{c}0.034 \\
{[0.011]}\end{array}$ \\
\hline \multicolumn{3}{|l|}{ Alternate Samples: } \\
\hline First births & 2,015 & $\begin{array}{c}0.044 \\
{[0.020]}\end{array}$ \\
\hline Low risk first births & 1,487 & $\begin{array}{c}0.040 \\
{[0.030]}\end{array}$ \\
\hline Excluding preterm births & 3,534 & $\begin{array}{c}0.049 \\
{[0.013]}\end{array}$ \\
\hline $\begin{array}{l}\text { Excluding births with contraindications for } \\
\text { attempting vaginal birth }\end{array}$ & 3,587 & $\begin{array}{c}0.042 \\
{[0.014]}\end{array}$ \\
\hline Excluding gestational ages over 41 weeks & 3,674 & $\begin{array}{c}0.033 \\
{[0.012]}\end{array}$ \\
\hline Excluding births 3 hours pre shift change & 3,297 & $\begin{array}{c}0.051 \\
{[0.015]}\end{array}$ \\
\hline Excluding births 3 hours post shift change & 3,313 & $\begin{array}{c}0.047 \\
{[0.012]}\end{array}$ \\
\hline Excluding births high volume shifts & 3,623 & $\begin{array}{c}0.036 \\
{[0.012]}\end{array}$ \\
\hline
\end{tabular}

Notes: Each cell is the coefficient on own patient from a separate regression. All regressions include the controls and fixed effects as indicated in Table 3, column (2). Standard errors, clustered by the DOB, are in brackets.

${ }^{\dagger}$ Contraindications for attempting vaginal birth are malpresented infants and placenta previa. 
Table A.3 The Physician-Patient Relationship and C-Section Decisions EXCLUDING INDIVIDUAL OBS

\begin{tabular}{|c|c|c|c|c|c|}
\hline \multirow[b]{2}{*}{ Excluded OB: } & \multicolumn{2}{|c|}{ Own Patient } & \multicolumn{2}{|c|}{$\begin{array}{l}\text { OB's Share of } \\
\text { Prenatal Visits }\end{array}$} & \multirow[b]{2}{*}{ Observations } \\
\hline & Coefficient & Std. Error & Coefficient & Std. Error & \\
\hline 1 & 0.040 & {$[0.011]$} & 0.060 & [0.013] & 3,658 \\
\hline 2 & 0.040 & {$[0.011]$} & 0.059 & [0.014] & 3,782 \\
\hline 3 & 0.047 & {$[0.010]$} & 0.069 & {$[0.010]$} & 3,515 \\
\hline 4 & 0.036 & {$[0.014]$} & 0.058 & [0.017] & 3,431 \\
\hline 5 & 0.044 & {$[0.011]$} & 0.062 & [0.013] & 3,551 \\
\hline 6 & 0.043 & [0.012] & 0.062 & [0.014] & 3,703 \\
\hline 7 & 0.042 & {$[0.012]$} & 0.061 & {$[0.014]$} & 3,755 \\
\hline 8 & 0.040 & {$[0.012]$} & 0.057 & {$[0.014]$} & 3,615 \\
\hline 9 & 0.042 & {$[0.011]$} & 0.060 & [0.014] & 3,651 \\
\hline 10 & 0.044 & {$[0.0100]$} & 0.063 & [0.014] & 3,403 \\
\hline 11 & 0.041 & {$[0.012]$} & 0.059 & {$[0.014]$} & 3,735 \\
\hline 12 & 0.042 & {$[0.012]$} & 0.061 & {$[0.014]$} & 3,596 \\
\hline 13 & 0.041 & [0.012] & 0.060 & [0.014] & 3,730 \\
\hline 14 & 0.040 & [0.012] & 0.060 & [0.015] & 3,424 \\
\hline 15 & 0.033 & {$[0.012]$} & 0.051 & [0.016] & 3,455 \\
\hline 16 & 0.033 & [0.013] & 0.053 & [0.017] & 3,435 \\
\hline 17 & 0.037 & [0.012] & 0.052 & [0.014] & 3,505 \\
\hline 18 & 0.038 & [0.012] & 0.056 & [0.014] & 3,737 \\
\hline 19 & 0.040 & [0.012] & 0.059 & {$[0.015]$} & 3,449 \\
\hline
\end{tabular}

Notes: Each cell contains the estimates from a separate regression. The first two columns reproduce Table 3, Column (3), with each regression excluding all the patients delivered by one OB as indicated. The last two columns reproduce Table 3, Column (6) in the same fashion. The estimation sample varies across rows depending on which DOB is excluded. Standard errors, clustered by the DOB, are in brackets. 
Table A.4 The Physician-Patient Relationship and C-Section Decisions LOGISTIC REGRESSION

\begin{tabular}{|c|c|c|c|c|c|c|}
\hline & (1) & $(2)$ & (3) & (4) & $(5)$ & (6) \\
\hline Own Patient & $\begin{array}{c}0.044 \\
{[0.015]}\end{array}$ & $\begin{array}{c}0.037 \\
{[0.011]}\end{array}$ & $\begin{array}{c}0.038 \\
{[0.010]}\end{array}$ & & & \\
\hline OB's Share of Prenatal Visits & & & & $\begin{array}{c}0.061 \\
{[0.016]}\end{array}$ & $\begin{array}{c}0.055 \\
{[0.014]}\end{array}$ & $\begin{array}{c}0.057 \\
{[0.012]}\end{array}$ \\
\hline $\begin{array}{l}\text { Controls? } \\
\text { Fixed Effects? }\end{array}$ & & Yes & $\begin{array}{l}\text { Yes } \\
\text { Yes }\end{array}$ & & Yes & $\begin{array}{l}\text { Yes } \\
\text { Yes }\end{array}$ \\
\hline $\begin{array}{l}\text { Observations } \\
\text { Pseudo } \mathrm{R}^{2}\end{array}$ & $\begin{array}{c}3,785 \\
0.0027\end{array}$ & $\begin{array}{c}3,785 \\
0.29\end{array}$ & $\begin{array}{c}3,785 \\
0.30\end{array}$ & $\begin{array}{c}3,785 \\
0.0032\end{array}$ & $\begin{array}{c}3,785 \\
0.29\end{array}$ & $\begin{array}{c}3,785 \\
0.31\end{array}$ \\
\hline
\end{tabular}


Table A.5 The Physician-Patient Relationship and C-Section Decisions DELIVERING OB $\times$ YEAR FIXED EFFECTS

\begin{tabular}{|c|c|c|c|c|c|c|c|c|}
\hline & (1) & (2) & (3) & (4) & (5) & (6) & (7) & (8) \\
\hline Own Patient & $\begin{array}{c}0.040 \\
{[0.012]}\end{array}$ & $\begin{array}{c}0.041 \\
{[0.011]}\end{array}$ & & & & & $\begin{array}{c}0.0059 \\
{[0.018]}\end{array}$ & $\begin{array}{l}0.0070 \\
{[0.019]}\end{array}$ \\
\hline OB's Share of Prenatal Visits & & & $\begin{array}{c}0.058 \\
{[0.014]}\end{array}$ & $\begin{array}{c}0.061 \\
{[0.014]}\end{array}$ & & & & \\
\hline OB's Number of Prenatal Visits & & & & & $\begin{array}{c}0.054 \\
{[0.0013]}\end{array}$ & $\begin{array}{c}0.056 \\
{[0.0013]}\end{array}$ & & \\
\hline Own Patient $\times$ Strong Relationship & & & & & & & $\begin{array}{c}0.067 \\
{[0.023]}\end{array}$ & $\begin{array}{c}0.066 \\
{[0.024]}\end{array}$ \\
\hline Strong Relationship & & & & & & & $\begin{array}{l}-0.011 \\
{[0.012]}\end{array}$ & $\begin{array}{c}-0.012 \\
{[0.012]}\end{array}$ \\
\hline
\end{tabular}

\begin{tabular}{lcccccccc} 
Delivering OB $\times$ Year Fixed Effects? & \multicolumn{3}{c}{ Yes } & \multicolumn{3}{c}{ Yes } & Yes & \multicolumn{2}{c}{ Yes } \\
\hline Observations & 3,785 & 3,785 & 3,785 & 3,785 & 3,785 & 3,785 & 3,785 & 3,785 \\
Adjusted R & 0.29 & 0.29 & 0.29 & 0.29 & 0.29 & 0.29 & 0.29 & 0.29 \\
\hline
\end{tabular}

Notes: Table displays results from OLS regressions of (1). All columns contain the full set of controls, prenatal provider and DOB fixed effects, as in Table 3, Column 2. Delivering OB $\times$ Year Fixed Effects are the full set of interactions of Year and DOB indicators. Standard errors, clustered by $\mathrm{DOB}$, are in brackets.

denotes significance at the $10 \%$ level, at the $5 \%$ level, and at the $1 \%$ level 


\section{Table A.6 AdDitional Decisions During LABor And Delivery}

\begin{tabular}{|c|c|c|c|c|c|c|c|c|}
\hline & \multicolumn{2}{|c|}{$\begin{array}{l}\text { Assisted Vaginal } \\
\text { Delivery }\end{array}$} & \multicolumn{2}{|c|}{$\begin{array}{c}\text { Length of } \\
\text { Second Stage }\end{array}$} & \multicolumn{2}{|c|}{$\begin{array}{c}\text { No Continuous } \\
\text { EFM }\end{array}$} & \multicolumn{2}{|c|}{ Ultrasound } \\
\hline & (1) & (2) & (3) & (4) & (5) & (6) & (7) & (8) \\
\hline Own Patient & $\begin{array}{c}-0.032 \\
{[0.011]}\end{array}$ & $\begin{array}{c}-0.025 \\
{[0.0100]}\end{array}$ & $\begin{array}{c}-0.18 \\
{[0.042]}\end{array}$ & $\begin{array}{c}-0.11 \\
{[0.051]}\end{array}$ & $\begin{array}{c}0.038 \\
{[0.0068]}\end{array}$ & $\begin{array}{c}0.035 \\
{[0.0078]}\end{array}$ & $\begin{array}{c}-0.016 \\
{[0.0073]}\end{array}$ & $\begin{array}{c}-0.017 \\
{[0.0064]}\end{array}$ \\
\hline
\end{tabular}

\begin{tabular}{|c|c|c|c|c|c|c|c|c|}
\hline Controls? & & Yes & & Yes & & Yes & & Yes \\
\hline Fixed Effects? & & Yes & & Yes & & Yes & & Yes \\
\hline Observations & 3,785 & 3,779 & 3,205 & 3,205 & 3,785 & 3,749 & 3,785 & 3,710 \\
\hline Adjusted $\mathrm{R}^{2}$ & 0.0026 & 0.13 & 0.0028 & 0.16 & 0.0049 & 0.043 & 0.0028 & 0.31 \\
\hline Mean of dependent variable & \multicolumn{2}{|c|}{0.0938} & \multicolumn{2}{|c|}{0.968} & \multicolumn{2}{|c|}{0.0922} & \multicolumn{2}{|c|}{0.0365} \\
\hline
\end{tabular}




\section{TAble A.7 Maternal Outcomes}

\begin{tabular}{|c|c|c|c|c|c|c|c|c|}
\hline \multirow[b]{2}{*}{ Panel A: Full Sample } & \multicolumn{2}{|c|}{ Any Complication } & \multicolumn{2}{|c|}{ Laceration Repair } & \multicolumn{2}{|c|}{ Fever } & \multicolumn{2}{|c|}{ Trauma } \\
\hline & (1) & (2) & (3) & (4) & (5) & (6) & (7) & (8) \\
\hline Own Patient & $\begin{array}{c}-0.032 \\
{[0.012]}\end{array}$ & $\begin{array}{c}-0.034 \\
{[0.012]}\end{array}$ & $\begin{array}{c}-0.044 \\
{[0.015]}\end{array}$ & $\begin{array}{c}-0.011 \\
{[0.0088]}\end{array}$ & $\begin{array}{c}-0.019 \\
{[0.0095]}\end{array}$ & $\begin{array}{c}-0.020 \\
{[0.0094]}\end{array}$ & $\begin{array}{c}-0.012 \\
{[0.0059]}\end{array}$ & $\begin{array}{c}-0.013 \\
{[0.0059]}\end{array}$ \\
\hline C-section & & $\begin{array}{c}0.086 \\
{[0.028]}\end{array}$ & & $\begin{array}{c}-0.71 \\
{[0.028]}\end{array}$ & & $\begin{array}{c}0.075 \\
{[0.017]}\end{array}$ & & $\begin{array}{c}0.021 \\
{[0.0091]}\end{array}$ \\
\hline Assisted Vaginal & & $\begin{array}{c}0.066 \\
{[0.021]}\end{array}$ & & $\begin{array}{c}-0.064 \\
{[0.020]}\end{array}$ & & $\begin{array}{c}0.053 \\
{[0.012]}\end{array}$ & & $\begin{array}{c}0.012 \\
{[0.0067]}\end{array}$ \\
\hline
\end{tabular}

\begin{tabular}{|c|c|c|c|c|c|c|c|c|}
\hline Controls? & Yes & Yes & Yes & Yes & Yes & Yes & Yes & Yes \\
\hline Fixed Effects? & Yes & Yes & Yes & Yes & Yes & Yes & Yes & Yes \\
\hline Observations & 3,782 & 3,782 & 3,785 & 3,785 & 3,752 & 3,752 & 3,589 & 3,589 \\
\hline Pseudo $\mathrm{R}^{2}$ & 0.067 & 0.076 & 0.12 & 0.39 & 0.15 & 0.18 & 0.078 & 0.086 \\
\hline Mean of dependent variable & \multicolumn{2}{|c|}{0.172} & \multicolumn{2}{|c|}{0.683} & \multicolumn{2}{|c|}{0.0741} & \multicolumn{2}{|c|}{0.0279} \\
\hline
\end{tabular}

\begin{tabular}{lcccccccc}
\hline Panel B: First Births & $(1)$ & $(2)$ & $(3)$ & $(4)$ & $(5)$ & $(6)$ & $(7)$ & $(8)$ \\
\hline Own Patient & -0.045 & -0.048 & -0.035 & 0.0028 & -0.025 & -0.026 & -0.025 & -0.025 \\
& {$[0.020]$} & {$[0.020]$} & {$[0.014]$} & {$[0.016]$} & {$[0.015]$} & {$[0.015]$} & {$[0.011]$} & {$[0.011]$} \\
C-section & & 0.12 & & -0.51 & & 0.12 & 0.011 \\
& & {$[0.033]$} & & {$[0.020]$} & & {$[0.024]$} & {$[0.012]$} \\
Assisted Vaginal Delivery & & 0.092 & & -0.035 & & 0.078 & 0.012 \\
& & {$[0.030]$} & & {$[0.014]$} & & {$[0.021]$} & {$[0.0091]$}
\end{tabular}

\begin{tabular}{|c|c|c|c|c|c|c|c|c|}
\hline Controls? & Yes & Yes & Yes & Yes & Yes & Yes & Yes & Yes \\
\hline Fixed Effects? & Yes & Yes & Yes & Yes & Yes & Yes & Yes & Yes \\
\hline Observations & 2,011 & 2,011 & 2,014 & 2,014 & 1,998 & 1,998 & 1,790 & 1,790 \\
\hline Pseudo $\mathrm{R}^{2}$ & 0.066 & 0.080 & 0.17 & 0.55 & 0.10 & 0.14 & 0.13 & 0.13 \\
\hline Mean of dependent variable & \multicolumn{2}{|c|}{0.228} & \multicolumn{2}{|c|}{0.688} & \multicolumn{2}{|c|}{0.121} & \multicolumn{2}{|c|}{0.0352} \\
\hline
\end{tabular}

Notes: Table contains average marginal effects from logistic regressions of the form $y_{i}=1\left(\alpha \mathrm{Own}_{i}+\mathbf{X}_{i}^{\prime} \beta+\zeta_{j(i)}+\eta_{p(i)}>\varepsilon_{i}\right)$. Standard errors, clustered by the DOB, are in brackets. 
TABle A. 8 Infant OUtComes

\begin{tabular}{|c|c|c|c|c|c|c|c|c|}
\hline \multirow[b]{2}{*}{ Panel A: Full Sample } & \multicolumn{2}{|c|}{ Any Respiratory Issues } & \multicolumn{2}{|c|}{ Serious Respiratory Issues } & \multicolumn{2}{|c|}{ Low Apgar } & \multicolumn{2}{|c|}{ Admission to NICU } \\
\hline & (1) & (2) & (3) & (4) & (5) & (6) & (7) & (8) \\
\hline Own Patient & $\begin{array}{c}-0.017 \\
{[0.012]}\end{array}$ & $\begin{array}{c}-0.016 \\
{[0.012]}\end{array}$ & $\begin{array}{c}-0.0093 \\
{[0.0070]}\end{array}$ & $\begin{array}{c}-0.0084 \\
{[0.0070]}\end{array}$ & $\begin{array}{c}0.012 \\
{[0.0089]}\end{array}$ & $\begin{array}{c}0.012 \\
{[0.0089]}\end{array}$ & $\begin{array}{c}-0.0029 \\
{[0.0078]}\end{array}$ & $\begin{array}{c}-0.0019 \\
{[0.0073]}\end{array}$ \\
\hline C-section & & $\begin{array}{c}0.041 \\
{[0.012]}\end{array}$ & & $\begin{array}{c}0.013 \\
{[0.0067]}\end{array}$ & & $\begin{array}{c}0.043 \\
{[0.015]}\end{array}$ & & $\begin{array}{c}0.037 \\
{[0.0095]}\end{array}$ \\
\hline Assisted Vaginal & & $\begin{array}{c}0.045 \\
{[0.0099]}\end{array}$ & & $\begin{array}{c}0.032 \\
{[0.0056]}\end{array}$ & & $\begin{array}{c}0.043 \\
{[0.011]}\end{array}$ & & $\begin{array}{c}0.026 \\
{[0.014]}\end{array}$ \\
\hline
\end{tabular}

\begin{tabular}{lcccccccc} 
Controls? & Yes & Yes & Yes & Yes & Yes & Yes & Yes & Yes \\
Fixed Effects? & Yes & Yes & Yes & Yes & Yes & Yes & Yes & Yes \\
\hline Observations & 3,180 & 3,180 & 3,065 & 3,065 & 3,150 & 3,150 & 3,160 & 3,160 \\
Pseudo R & 0.17 & 0.18 & 0.11 & 0.12 & 0.095 & 0.11 & 0.26 & 0.27 \\
\hline Mean of dependent variable & \multicolumn{2}{c}{0.0962} & \multicolumn{2}{c}{0.0388} & & 0.0511 & & 0.0570 \\
\hline
\end{tabular}

\begin{tabular}{lcccccccc}
\hline Panel B: First Births & $(1)$ & $(2)$ & $(3)$ & $(4)$ & $(5)$ & $(6)$ & $(7)$ & $(8)$ \\
\hline Own Patient & -0.045 & -0.044 & -0.016 & -0.015 & 0.0086 & 0.0081 & -0.018 & -0.017 \\
& {$[0.018]$} & {$[0.018]$} & {$[0.015]$} & {$[0.014]$} & {$[0.015]$} & {$[0.015]$} & {$[0.013]$} & {$[0.012]$} \\
C-section & & 0.020 & & 0.0033 & & 0.045 & 0.035 \\
& & {$[0.020]$} & & {$[0.011]$} & & {$[0.014]$} & {$[0.017]$} \\
Assisted Vaginal Delivery & & 0.034 & & 0.021 & & 0.042 & 0.017 \\
& & {$[0.013]$} & & {$[0.010]$} & & {$[0.012]$} & {$[0.021]$}
\end{tabular}

\begin{tabular}{lcccccccc} 
Controls? & Yes & Yes & Yes & Yes & Yes & Yes & Yes & Yes \\
Fixed Effects? & Yes & Yes & Yes & Yes & Yes & Yes & Yes & Yes \\
\hline Observations & 1,680 & 1,680 & 1,477 & 1,477 & 1,666 & 1,666 & 1,667 & 1,667 \\
Pseudo R & 0.21 & 0.21 & 0.16 & 0.16 & 0.11 & 0.13 & 0.28 & 0.29 \\
\hline Mean of dependent variable & \multicolumn{2}{c}{0.110} & & 0.0460 & 0.0630 & 0.0678 \\
\hline
\end{tabular}

Notes: Table contains average marginal effects from logistic regressions of the form $y_{i}=1\left(\alpha \mathrm{Own}_{i}+\mathbf{X}_{i}^{\prime} \beta+\zeta_{j(i)}+\eta_{p(i)}>\varepsilon_{i}\right)$. Low Apgar is an indicator the infant had a 1-minute Apgar score below 7. Standard errors, clustered by the DOB, are in brackets. 
Table A.9 Length of Hospital Stay in Days

\begin{tabular}{|c|c|c|c|c|}
\hline \multirow[b]{3}{*}{ Panel A: Full Sample } & \multicolumn{4}{|c|}{ Length of Stay from Birth to Recovery } \\
\hline & \multicolumn{2}{|c|}{ Mothers } & \multicolumn{2}{|c|}{ Infants } \\
\hline & (1) & (2) & (3) & (4) \\
\hline Own Patient & $\begin{array}{c}0.077 \\
{[0.022]}\end{array}$ & $\begin{array}{c}-0.0018 \\
{[0.024]}\end{array}$ & $\begin{array}{l}0.041 \\
{[0.17]}\end{array}$ & $\begin{array}{l}-0.011 \\
{[0.16]}\end{array}$ \\
\hline C-section & & $\begin{array}{c}2.06 \\
{[0.040]}\end{array}$ & & $\begin{array}{c}1.92 \\
{[0.28]}\end{array}$ \\
\hline Assisted Vaginal Delivery & & $\begin{array}{c}0.067 \\
{[0.043]}\end{array}$ & & $\begin{array}{c}0.20 \\
{[0.16]}\end{array}$ \\
\hline Controls? & Yes & Yes & Yes & Yes \\
\hline Fixed Effects? & Yes & Yes & Yes & Yes \\
\hline Observations & 3,783 & 3,783 & 3,202 & 3,202 \\
\hline Adjusted $\mathrm{R}^{2}$ & 0.23 & 0.67 & 0.43 & 0.44 \\
\hline Mean of dependent variable & \multicolumn{2}{|c|}{2.47} & \multicolumn{2}{|c|}{3.22} \\
\hline
\end{tabular}

\begin{tabular}{lcccc}
\hline Panel B: First Births & $(1)$ & $(2)$ & $(3)$ & $(4)$ \\
\hline Own Patient & 0.11 & 0.025 & 0.20 & 0.12 \\
& {$[0.058]$} & {$[0.027]$} & {$[0.34]$} & {$[0.31]$} \\
C-section & & 2.08 & & 2.35 \\
& & {$[0.045]$} & & {$[0.28]$} \\
Assisted Vaginal Delivery & & 0.066 & 0.16 \\
& & {$[0.038]$} & & $0.18]$
\end{tabular}

\begin{tabular}{lcccc} 
Controls? & Yes & Yes & Yes & Yes \\
Fixed Effects? & Yes & Yes & Yes & Yes \\
\hline Observations & 2,013 & 2,013 & 1,697 & 1,697 \\
Adjusted R & 2.20 & 0.70 & 0.49 & 0.50 \\
\hline Mean of dependent variable & \multicolumn{2}{c}{2.66} & \multicolumn{2}{c}{3.73} \\
\hline
\end{tabular}

Notes: Table contains estimates from OLS regressions of (1). Standard errors, clustered by the DOB, are in brackets. 
Table A.10 Length of Hospital Stay

\begin{tabular}{|c|c|c|c|c|}
\hline \multirow[b]{3}{*}{ Panel A: Full Sample } & \multicolumn{4}{|c|}{ Log Length of Stay (Birth to Discharge) } \\
\hline & \multicolumn{2}{|c|}{ Mothers } & \multicolumn{2}{|c|}{ Infants } \\
\hline & (1) & (2) & (3) & (4) \\
\hline Own Patient & $\begin{array}{c}0.020 \\
{[0.0076]}\end{array}$ & $\begin{array}{c}-0.0050 \\
{[0.0075]}\end{array}$ & $\begin{array}{c}0.013 \\
{[0.015]}\end{array}$ & $\begin{array}{l}-0.0048 \\
{[0.010]}\end{array}$ \\
\hline C-section & & $\begin{array}{c}0.67 \\
{[0.0087]}\end{array}$ & & $\begin{array}{c}0.64 \\
{[0.016]}\end{array}$ \\
\hline Assisted Vaginal Delivery & & $\begin{array}{c}0.031 \\
{[0.017]}\end{array}$ & & $\begin{array}{c}0.048 \\
{[0.021]}\end{array}$ \\
\hline Controls? & Yes & Yes & Yes & Yes \\
\hline Fixed Effects? & Yes & Yes & Yes & Yes \\
\hline Observations & 3,779 & 3,779 & 3,198 & 3,198 \\
\hline Adjusted $\mathrm{R}^{2}$ & 0.23 & 0.63 & 0.40 & 0.54 \\
\hline Mean of dependent variable & \multicolumn{2}{|c|}{0.845} & \multicolumn{2}{|c|}{0.906} \\
\hline Panel B: First Births & (1) & (2) & (3) & (4) \\
\hline Own Patient & $\begin{array}{c}0.036 \\
{[0.018]}\end{array}$ & $\begin{array}{c}0.0091 \\
{[0.0069]}\end{array}$ & $\begin{array}{c}0.016 \\
{[0.027]}\end{array}$ & $\begin{array}{l}-0.0051 \\
{[0.018]}\end{array}$ \\
\hline C-section & & $\begin{array}{c}0.67 \\
{[0.011]}\end{array}$ & & $\begin{array}{c}0.66 \\
{[0.028]}\end{array}$ \\
\hline Assisted Vaginal Delivery & & $\begin{array}{c}0.034 \\
{[0.014]}\end{array}$ & & $\begin{array}{c}0.043 \\
{[0.020]}\end{array}$ \\
\hline Controls? & Yes & Yes & Yes & Yes \\
\hline Fixed Effects? & Yes & Yes & Yes & Yes \\
\hline Observations & 2,013 & 2,013 & 1,696 & 1,696 \\
\hline Adjusted $\mathrm{R}^{2}$ & 0.20 & 0.71 & 0.43 & 0.60 \\
\hline Mean of dependent variable & & 15 & & \\
\hline
\end{tabular}

Notes: Table contains estimates from OLS regressions of (1) using log number of days from birth to discharge. Standard errors, clustered by the DOB, are in brackets. 6 mothers with 0 length of stay were excluded from the analysis. 
Table A.11 Weak Ties And C-Section Decisions

\begin{tabular}{lcccccc}
\hline & $(1)$ & $(2)$ & $(3)$ & $(4)$ & $(5)$ & $(6)$ \\
\hline Own Patient & 0.078 & 0.057 & 0.055 & 0.056 & 0.048 & 0.044 \\
& {$[0.023]$} & {$[0.016]$} & {$[0.0061]$} & {$[0.019]$} & {$[0.016]$} & {$[0.014]$} \\
Patient from Own Practice & 0.0077 & 0.017 & 0.018 & & & \\
& {$[0.020]$} & {$[0.0066]$} & {$[0.0077]$} & & & \\
Ever Met Patient & & & & -0.012 & -0.013 & -0.0052 \\
& & & & {$[0.019]$} & {$[0.019]$} & {$[0.016]$} \\
& & & & & & \\
Controls? & & Yes & Yes & & Yes & Yes \\
Fixed Effects? & & & Yes & & & Yes \\
\hline Observations & 1,894 & 1,894 & 1,894 & 3,785 & 3,785 & 3,785 \\
Adjusted R & 0.0078 & 0.29 & 0.29 & 0.0022 & 0.28 & 0.29 \\
\hline
\end{tabular}

Notes: Table displays results from OLS regressions of a C-section indicator on the own patient indicator, with controls and fixed effects defined as in Table 3. In Columns (1) - (3) the sample is limited to Groups B and C, the two practices that share call across practices. Regressions in Columns (1) - (3) include an indicator that the patient's primary prenatal OB is from the DOB's practice group. Columns (4) - (6) are estimated on the full sample and include an indicator that the DOB had at least 1 prenatal visit with the patient. Standard errors, clustered by DOB, are in brackets. 
TABle A.12 C-SECTION DeCisions IN LAST OR ONLy LABORS

\begin{tabular}{|c|c|c|c|c|c|c|}
\hline & (1) & (2) & (3) & (4) & (5) & (6) \\
\hline Own Patient & $\begin{array}{c}0.043 \\
{[0.023]}\end{array}$ & $\begin{array}{c}0.035 \\
{[0.017]}\end{array}$ & $\begin{array}{c}0.037 \\
{[0.020]}\end{array}$ & $\begin{array}{c}0.038 \\
{[0.018]}\end{array}$ & $\begin{array}{c}0.037 \\
{[0.015]}\end{array}$ & $\begin{array}{c}0.039 \\
{[0.016]}\end{array}$ \\
\hline Last Labor in Shift & $\begin{array}{l}0.0057 \\
{[0.018]}\end{array}$ & $\begin{array}{l}0.0047 \\
{[0.012]}\end{array}$ & $\begin{array}{l}0.0054 \\
{[0.011]}\end{array}$ & & & \\
\hline Own Patient $\times$ Last Labor in Shift & $\begin{array}{c}0.013 \\
{[0.046]}\end{array}$ & $\begin{array}{c}0.012 \\
{[0.038]}\end{array}$ & $\begin{array}{c}0.011 \\
{[0.039]}\end{array}$ & & & \\
\hline Only Labor in Shift & & & & $\begin{array}{l}-0.0022 \\
{[0.021]}\end{array}$ & $\begin{array}{l}0.0089 \\
{[0.016]}\end{array}$ & $\begin{array}{c}0.012 \\
{[0.015]}\end{array}$ \\
\hline Own Patient $\times$ Only Labor in Shift & & & & $\begin{array}{c}0.049 \\
{[0.042]}\end{array}$ & $\begin{array}{l}0.0088 \\
{[0.042]}\end{array}$ & $\begin{array}{l}0.0029 \\
{[0.043]}\end{array}$ \\
\hline $\begin{array}{l}\text { Controls? } \\
\text { Fixed Effects? }\end{array}$ & & Yes & $\begin{array}{l}\text { Yes } \\
\text { Yes }\end{array}$ & & Yes & $\begin{array}{l}\text { Yes } \\
\text { Yes }\end{array}$ \\
\hline $\begin{array}{l}\text { Observations } \\
\text { Adjusted } \mathrm{R}^{2}\end{array}$ & $\begin{array}{c}3,785 \\
0.0019\end{array}$ & $\begin{array}{c}3,785 \\
0.28\end{array}$ & $\begin{array}{c}3,785 \\
0.29\end{array}$ & $\begin{array}{c}3,785 \\
0.0022\end{array}$ & $\begin{array}{c}3,785 \\
0.28\end{array}$ & $\begin{array}{c}3,785 \\
0.29\end{array}$ \\
\hline
\end{tabular}

Notes: Table displays results from OLS regressions of a C-section indicator on the own patient indicator, with controls and fixed effects defined as in Table 3. Standard errors, clustered by DOB, are in brackets. 
TABle A.13 Testing During Labor ANd Delivery

\begin{tabular}{|c|c|c|c|c|c|c|c|c|}
\hline & \multicolumn{2}{|c|}{ Total Tests } & \multicolumn{2}{|c|}{ Diabetes Panel } & \multicolumn{2}{|c|}{ Infection Screening } & \multicolumn{2}{|c|}{ Ultrasound } \\
\hline & (1) & (2) & (3) & (4) & (5) & (6) & (7) & (8) \\
\hline Own Patient & $\begin{array}{l}-0.0027 \\
{[0.0053]}\end{array}$ & $\begin{array}{c}-0.0074 \\
{[0.0067]}\end{array}$ & $\begin{array}{l}0.0013 \\
{[0.010]}\end{array}$ & $\begin{array}{c}0.0027 \\
{[0.0091]}\end{array}$ & $\begin{array}{c}-0.015 \\
{[0.0098]}\end{array}$ & $\begin{array}{c}-0.010 \\
{[0.0085]}\end{array}$ & $\begin{array}{c}-0.016 \\
{[0.0073]}\end{array}$ & $\begin{array}{c}-0.017 \\
{[0.0064]}\end{array}$ \\
\hline
\end{tabular}

\begin{tabular}{|c|c|c|c|c|c|c|c|c|}
\hline Controls? & \multicolumn{3}{|c|}{ Yes } & Yes & \multicolumn{3}{|c|}{ Yes } & Yes \\
\hline Fixed Effects? & \multicolumn{3}{|c|}{ Yes } & Yes & \multicolumn{3}{|c|}{ Yes } & Yes \\
\hline Observations & 3,785 & 2,989 & 3,785 & 3,588 & 3,785 & 3,747 & 3,785 & 3,710 \\
\hline Adj./Pseudo $\mathrm{R}^{2}$ & 0.00038 & 0.062 & 0.0000086 & 0.22 & 0.0010 & 0.18 & 0.0028 & 0.31 \\
\hline Mean of dependent variable & \multicolumn{2}{|c|}{6.11} & \multicolumn{2}{|c|}{0.0637} & \multicolumn{2}{|c|}{0.0676} & \multicolumn{2}{|c|}{0.0365} \\
\hline
\end{tabular}

Notes: Columns (1) - (2) contain OLS estimates of (1). Columns (3) - (8) contain average marginal effects from logistic regressions of the form $y_{i}=1\left(\alpha \mathrm{Own}_{i}+\mathbf{X}_{i}^{\prime} \beta+\zeta_{j(i)}+\eta_{p(i)}>\varepsilon_{i}\right)$. Diabetes panel includes tests commonly used to evaluate health of diabetic patients during labor. Those tests include point-of-care glucose and hemoglobin A1C tests. Standard errors, clustered by the DOB, are in brackets. 